\title{
Rheology and TIC/TOC Results of ORNL Tank Samples
}

\author{
J. M. Pareizs \\ E. K. Hansen
}

April 2013

Savannah River National Laboratory Savannah River Nuclear Solutions, LLC Aiken, SC 29808

Prepared for the U.S. Department of Energy under contract number DE-AC09-08SR22470. 
SRNL-STI-2013-00299

Revision 0

\section{DISCLAIMER}

This work was prepared under an agreement with and funded by the U.S. Government. Neither the U.S. Government or its employees, nor any of its contractors, subcontractors or their employees, makes any express or implied:

1. warranty or assumes any legal liability for the accuracy, completeness, or for the use or results of such use of any information, product, or process disclosed; or

2. representation that such use or results of such use would not infringe privately owned rights; or

3. endorsement or recommendation of any specifically identified commercial product, process, or service.

Any views and opinions of authors expressed in this work do not necessarily state or reflect those of the United States Government, or its contractors, or subcontractors.

\section{Printed in the United States of America}

Prepared for

U.S. Department of Energy 
Keywords: ORNL, SLUDGE, SLURRY, RHEOLOGY, TIC, TOC

Retention: Permanent

\section{Rheology and TIC/TOC Results of ORNL Tank Samples}

J. M. Pareizs

E. K. Hansen

\section{April 2013}

Savannah River National Laboratory Savannah River Nuclear Solutions, LLC Aiken, SC 29808

Prepared for the U.S. Department of Energy under contract number DE-AC09-08SR22470. 


\section{REVIEWS AND APPROVALS}

AUTHORS:

J. M. Pareizs, Process Technology Programs

Date

E. K. Hansen, Process Technology Programs

Date

TECHNICAL REVIEW:

M. E. Stone, Process Technology Programs

Date

APPROVAL:

C. C. Herman, Manager

Date

Process Technology Programs

S.L. Marra, Manager

Date

Environmental \& Chemical Process Technology Research Programs 


\section{TABLE OF CONTENTS}

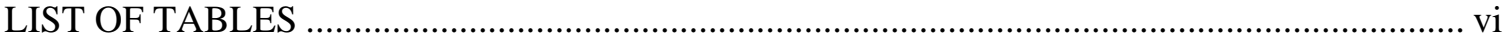

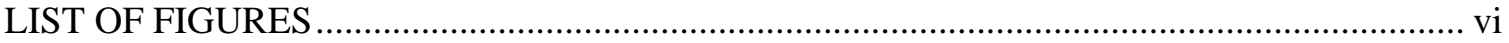

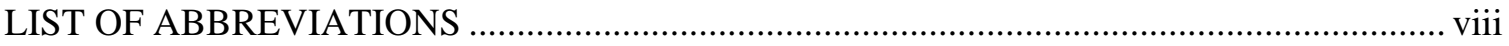

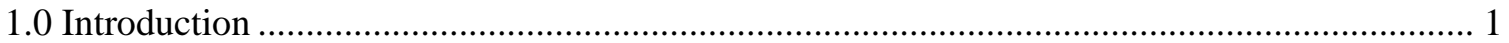

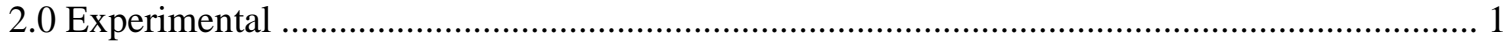

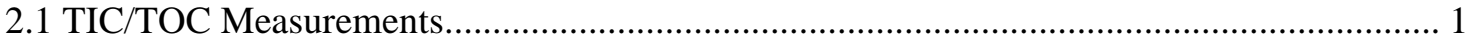

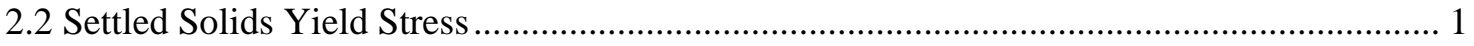

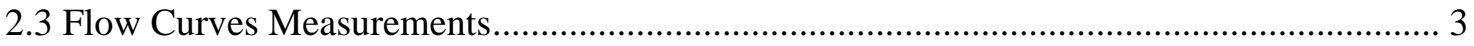

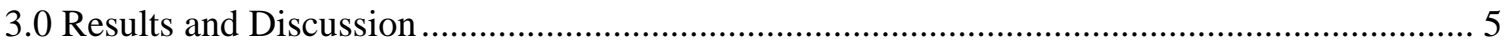

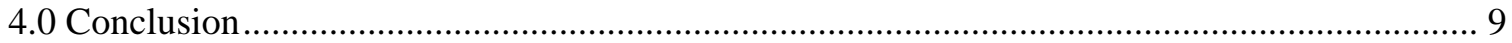

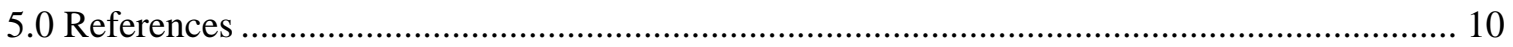

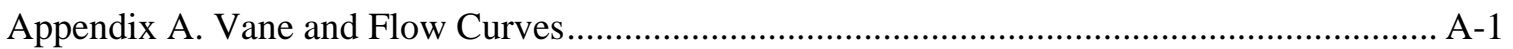




\section{LIST OF TABLES}

Table 2-1. MV I Rotor Specifications and Flow Curve Program................................................. 5

Table 3-1. Total Inorganic and Organic Carbon Results ............................................................. 5

Table 3-2. Vane 24 Hour Settled Solids Yield Stress of As-Received ORNL Samples ................ 5

Table 3-3. Bingham Plastic Yield Stress and Plastic Viscosity For ORNL Samples.................... 7

\section{LIST OF FIGURES}

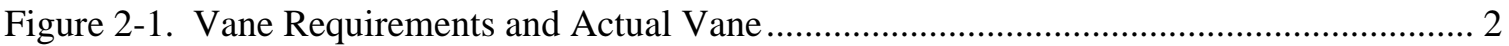

Figure 2-2. Typical Vane Torque Versus Time/Displacement Curve .......................................... 3

Figure 3-1 Bingham Plastic Yield Stress Versus Wt\% TSS for ORNL-24/25/28/30 Sludges........ 8

Figure 3-2 Plastic Viscosity Versus Wt\% TSS for ORNL-24/25/28/30 Sludges.......................... 8

Figure A-1. ORNL-24 Vane Curve, 0.6 RPM..................................................................... 1

Figure A-2. ORNL-25 Vane Curve, 0.6 RPM........................................................................ 1

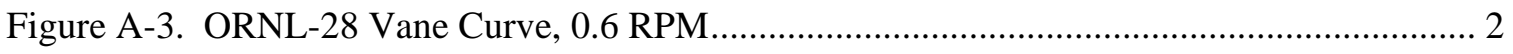

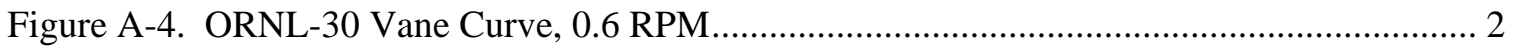

Figure A-5. ORNL-24 As-Received Flow Curve, $1^{\text {st }}$ Measurement ............................................ 3

Figure A-6. ORNL-24 15\% TSS Flow Curve, $1^{\text {st }}$ Measurement................................................. 3

Figure A-7. ORNL-24 15\% TSS Flow Curve, $2^{\text {nd }}$ Measurement............................................... 4

Figure A-8. ORNL-24 10\% TSS Flow Curve, $1^{\text {st }}$ Measurement................................................... 4

Figure A-9. ORNL-24 10\% TSS Flow Curve, $2^{\text {nd }}$ Measurement................................................ 5

Figure A-10. ORNL-25 As-Received Flow Curve, $1^{\text {st }}$ Measurement ............................................ 5

Figure A-11. ORNL-25 As-Received Flow Curve, $2^{\text {nd }}$ Measurement ......................................... 6

Figure A-12. ORNL-25 As-Received Flow Curve, $3^{\text {rd }}$ Measurement .......................................... 6

Figure A-13. ORNL-25 15\% TSS Flow Curve, $2^{\text {nd }}$ Measurement .............................................. 7

Figure A-14. ORNL-25 10\% TSS Flow Curve, $1^{\text {st }}$ Measurement............................................... 7

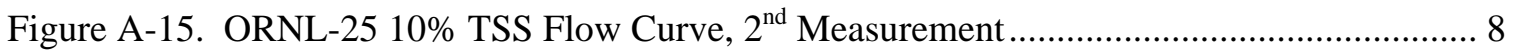


Figure A-16. ORNL-28 As-Received Flow Curve, $1^{\text {st }}$ Measurement ........................................... 8

Figure A-17. ORNL-28 10\% TSS Flow Curve, $1^{\text {st }}$ Measurement................................................ 9

Figure A-18. ORNL-28 10\% TSS Flow Curve, $2^{\text {nd }}$ Measurement............................................. 9

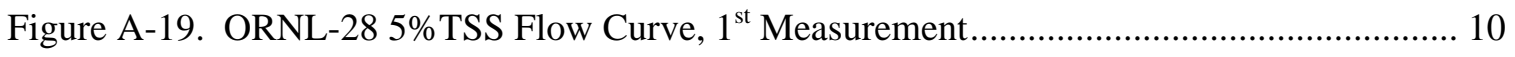

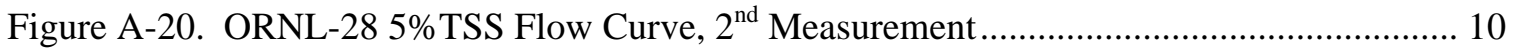

Figure A-21. ORNL-30 As-Received Flow Curve, $1^{\text {st }}$ Measurement ......................................... 11

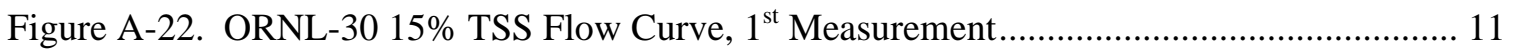

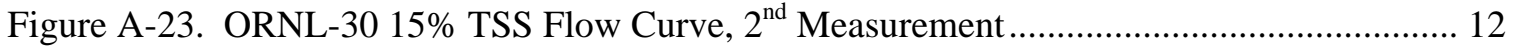

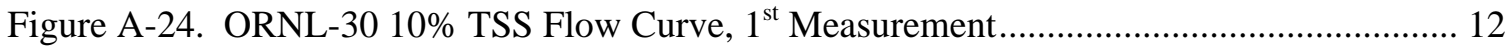

Figure A-25. ORNL-30 10\% TSS Flow Curve, $2^{\text {nd }}$ Measurement.............................................. 13 


\section{LIST OF ABBREVIATIONS}

$\begin{array}{ll}\text { ORNL } & \text { Oak Ridge National Laboratory } \\ \text { SRNL } & \text { Savannah River National Laboratory } \\ \text { SSYS } & \text { Settled Solids Yield Stress } \\ \text { TIC } & \text { Total Inorganic Carbon } \\ \text { TOC } & \text { Total Organic Carbon } \\ \text { TSS } & \text { total suspended solids }\end{array}$




\subsection{Introduction}

The Savannah River National Laboratory (SRNL)) was requested by Oak Ridge National Laboratory (ORNL) to perform total inorganic carbon (TIC), total organic carbon (TOC), and rheological measurements for several Oak Ridge tank samples. The tanks designated by ORNL are $\mathrm{W}-24, \mathrm{~W}-25, \mathrm{~W}-28$, and $\mathrm{W}-30$. In this report, the samples are designated as ORNL-24, ORNL-25, ORNL-28, and ORNL-30 respectively.

As received slurry samples were diluted and submitted to SRNL-Analytical for TIC and TOC analyses.

Settled solids yield stress (also known as settled shear strength) of the as received settled sludge samples were determined using the vane method and these measurements were obtained 24 hours after the samples were allowed to settled undisturbed.

Rheological or flow properties (Bingham Plastic viscosity and Bingham Plastic yield stress) were determined from flow curves of the homogenized or well mixed samples. Other targeted total suspended solids (TSS) concentrations samples were also analyzed for flow properties and these samples were obtained by diluting the as-received sample with de-ionized (DI) water.

\subsection{Experimental}

\subsection{TIC/TOC Measurements}

Total inorganic carbon (TIC) and total organic carbon (TOC) samples were prepared for analysis by diluting sub-samples of the as-received samples by 20x using DI water. Dilutions were performed in duplicate.

\subsection{Settled Solids Yield Stress}

As received slurry samples were mixed by shaking the sample bottles. The slurries were then poured into separate containers and allowed to settle overnight prior to performing the vane measurement.

Vanes have been used to measure the yield stress of non-Newtonian fluids as shown in Figure 2-1. 1,2,3,4,5,6,7 The vane is inserted into the fluid and is rotated at a very slow speed, unlike in flow curve measurement (see section 2.3). The surface area that the vane cuts through the sample is used to determine the shear stress. This surface area is that of a cylinder, which are defined by the diameter and height of the vane. It has been shown that this is a good assumption for determining the yield stress of the fluid using the vane. ${ }^{6,7}$ Equation [2-1] is used to determine the SSYS and it assumes the stress is constant on all surfaces and the sample satisfies all the dimensional requirements shown in Figure 2-1 for subsurface vane measurements. Due to the sample volume available for this measurement, the vane was inserted into the sample such that the top of the vane is located near the top of the sample surface with all the other geometric requirements satisfied. In this case, an additional assumption is made such that the top surface of the vane (circle) experiences no stress from the fluid, whereas all the other surfaces experience the same shear stress. This requires equation [2-1] to be slightly modified to exclude shear stress contribution from the top surface, resulting in equation [2-2]. 


$$
\tau=\frac{\Gamma}{\frac{\pi \cdot D^{3}}{2}\left(\frac{H}{D}+\frac{1}{3}\right)}=A \cdot \Gamma, A=\frac{2}{\pi \cdot D^{3}\left(\frac{H}{D}+\frac{1}{3}\right)}\left(\frac{1}{m^{3}} \text { or } \frac{P a}{N \cdot m}\right)
$$

Where $\Gamma=$ measured torque or measured $\%$ torque $(\mathrm{N} \cdot \mathrm{m}$ or $\%$ torque)

$\mathrm{D}=$ diameter of vane $(\mathrm{m})$

$\mathrm{H}=$ height of vane $(\mathrm{m})$

$\mathrm{A}=$ geometric constant $\left(\mathrm{Pa} /(\mathrm{N} \cdot \mathrm{m})\right.$ or $\left.\mathrm{Pa} \Gamma_{\max } /(100 \%)\right)$

$$
\tau_{\text {surface }}=\frac{\Gamma}{\frac{\pi \cdot D^{3}}{2}\left(\frac{H}{D}+\frac{1}{6}\right)}=A_{\text {surface }} \cdot \Gamma, A_{\text {surface }}=\frac{2}{\pi \cdot D^{3}\left(\frac{H}{D}+\frac{1}{6}\right)}\left(\frac{P a}{N \cdot m} \operatorname{or} \frac{P a}{\% \Gamma}\right)
$$

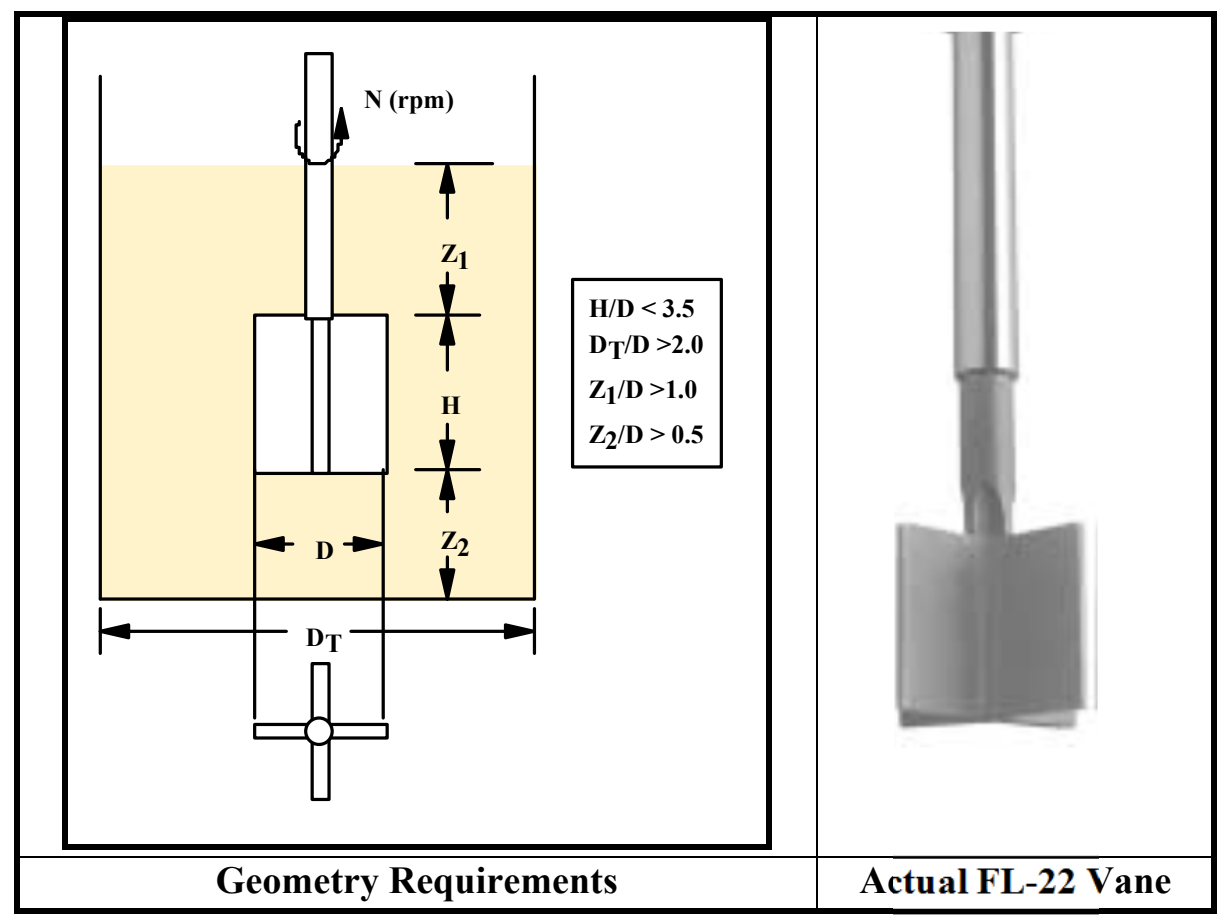

Figure 2-1. Vane Requirements and Actual Vane

A typical stress versus time (or displacement) curve for a vane measurement is shown in Figure 2-2. The initial vane response for a non-Newtonian fluid having a yield stress is typically linear with a slope that is called the Hookean elastic modulus (G). The point of departure from this linear region, called the static yield stress, ${ }^{1}$ occurs when the fluid starts to transition from a fully elastic to viscoelastic behavior. At the maximum stress, the behavior of the material transitions between viscoelastic and fully viscous and is called the yield stress (also known as the dynamic yield stress). This maximum shear stress is the reported SSYS. 
SRNL-STI-2013-00299

Revision 0

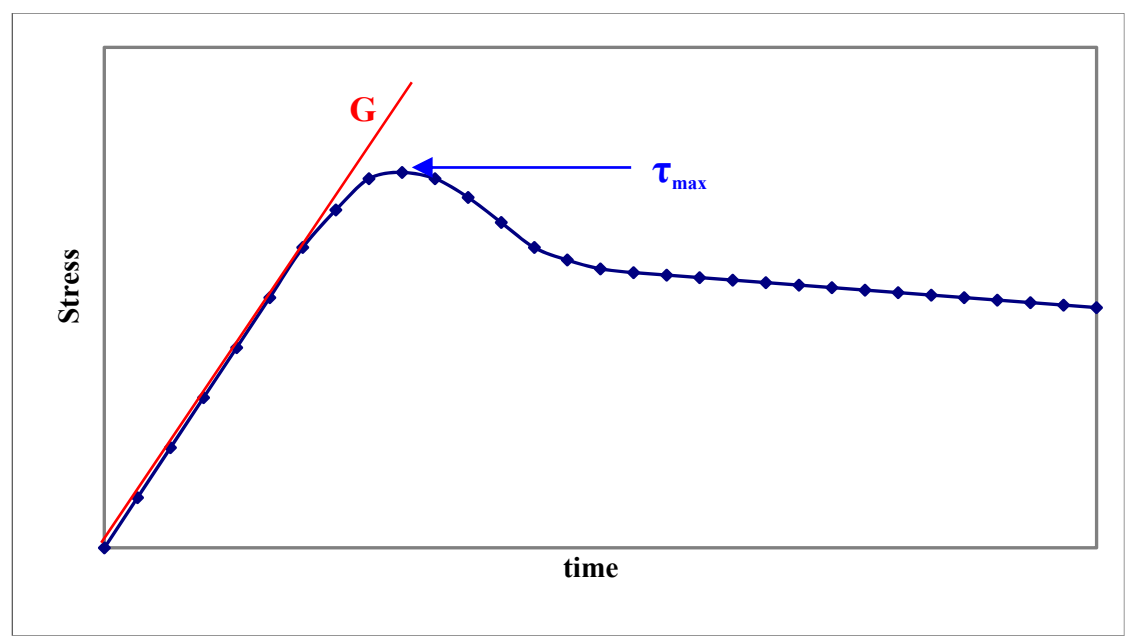

Figure 2-2. Typical Vane Torque Versus Time/Displacement Curve

The vane dimensions used are $\mathrm{H}=16 \mathrm{~mm}$ and $\mathrm{D}=22 \mathrm{~mm}$. The Haake $\mathrm{M} 5$ measuring head and RV30 controller were used to perform these measurements and the maximum torque of the M5 measuring head is $4.9 \mathrm{~N} \cdot \mathrm{cm}$. The A factor for this vane given the surface measuring condition is shown in equation [2-3].

$$
A=\frac{2}{\pi \cdot(0.022 m)^{3} \cdot\left(\left(\frac{16}{22}\right)+\frac{1}{6}\right)} \cdot \frac{1}{m^{3}} \frac{P a}{\frac{N}{m^{2}}} \cdot \frac{4.9 N \cdot c m}{100 \% \Gamma} \cdot \frac{m}{100 \mathrm{~cm}}=32.77 \frac{P a}{\% \Gamma}
$$

The vane rotational speed for measuring the SSYS used at SRNL is 0.3 RPM. This rotational speed was attempted for these ORNL samples, but the resulting vane response could not be analyzed due to the erratic responses. The reason for these erratic responses could be due to the ability of this specific instrument to control this targeted rotational speed. The vane rotational speed was then increased to 0.6 RPM, a rotational speed that is still acceptable for vane measurements. Increasing the rotational speed could result in a higher shear stress curve.

\subsection{Flow Curves Measurements}

The rheological properties of the as received samples and samples diluted with DI water to target wt $\%$ TSS were calculated from flow curve measurements. Because of limited sample volume of the as-received ORNL samples, the diluted wt\% TSS were calculated rather than being measured. The $w t \%$ TSS of the original ORNL samples were provided by ORNL. The wt\% TSS of the diluted samples was calculated using equation [2-4] from subsamples taken from the original ORNL samples.

$$
(w t \% T S S)_{\text {diluted }}=\frac{\text { mass of TSS in original subsample }}{\text { mass of original subsample }+ \text { mass of DI water add }} \times 100 \%
$$

Rheological properties were determined using a Haake M5/RV30 rotoviscometer. The M5/RV30 is a Searle sensor system, where the bob (cylindrical in shape) rotates on a central shaft, and the 
cup is fixed, with the fluid between the two surfaces. The torque and rotational speed of the bob are measured. Heating/cooling of the cup/sample/bob is through the holder for the cup. The shear stress is determined from the torque measurement and is independent of the rheological properties. Conditions that impact the measured torque are; slip (material does not properly adhere to the rotor or cup), phase separation (buildup of liquid layer on rotor), sedimentation (particles settling out of the shearing zone), homogeneous sample (void of air), lack of sample (gap not filled), excess sample (primarily impacts rheologically thin fluids), completely filling up the void below the bob (air buffer that is now filled with fluid) and Taylor vortices. The first five items yield lower stresses and the last three add additional stresses. Particles larger than or near the size of the gap between the bob and cup can impact the measurement by generating stress spikes in the flow curve and these spikes have to be removed to analyze the flow curve. These larger particles are typically very low in concentration and their impact is typically observed during the initial ramping in the up curve measurement. The shear rate is geometrically determined using the equations of change (continuity and motion) and is that for a Newtonian fluid. This assumption also assumes that the flow field is fully developed and the flow is laminar. The shear rate can be calculated for non-Newtonian fluids using the measured data and fitting this data to the rheological model or corrected as recommended by Darby ${ }^{8}$. In either case, for shear thinning non-Newtonian fluids typical of sludge wastes, the corrected shear rates are greater than their corresponding Newtonian shear rates, resulting in a mathematically thinner fluid. Correcting the flow curves will not be performed in this task, resulting in calculations giving a slightly more viscous fluid. The bob/cup combination typically used for measuring sludge at SRNL is the MV I rotor. The shape, dimensions, and geometric constants for the MV I rotor are provided in Table 2-1.

The flow curves for the sludge were fitted to the down curves from $600 \mathrm{sec}^{-1}$ to $50 \mathrm{sec}^{-1}$ using the Bingham Plastic rheological model, Equation [2-5], where $\tau$ is the measured stress $(\mathrm{Pa}), \tau_{0}$ is the Bingham Plastic yield stress (Pa), $\mu_{\infty}$ is the plastic viscosity (Pa-sec), and $\dot{\gamma}$ is the measured shear rate $\left(\mathrm{sec}^{-1}\right)$. Either the up or down curve from the flow curve measurement can be analyzed. For cases where the fluids show thixotropic properties, e.g., the down curve is below the up curve, the down curve is typically analyzed and reported. The down curve is also more representative of processes such as continuously mixed vessels. These samples also contained larger particulates (close to the gap size between the bob-cup) which generate spikes (due to jamming of the particles between the bob/cup) and removal of these spike responses were necessary in some of the samples to allow for assessing the data. During all these measurements, the sample remained in the cup for a second or third measurement, due to the limited sample availability and the flow curve for these subsequent measurements were manually corrected for a yield stress off set that is inherit to the instrument and dependent on the sample.

$$
\tau=\tau_{o}+\mu_{\infty} \dot{\gamma}
$$


Table 2-1. MV I Rotor Specifications and Flow Curve Program

\begin{tabular}{|c|c|c|}
\hline Rotor Design & \multicolumn{2}{|c|}{ Dimensions and Flow Curve Program } \\
\hline & Rotor Type & MV I \\
\hline & Rotor radius $-\mathrm{R}_{\mathrm{i}}(\mathrm{mm})$ & 20.04 \\
\hline & Cup Radius - $\mathrm{R}_{\mathrm{a}}(\mathrm{mm})$ & 21.0 \\
\hline & Height of rotor $-\mathrm{L}(\mathrm{mm})$ & 60 \\
\hline & $\begin{array}{c}\text { Sample Volume }\left(\mathrm{cm}^{3}\right) \\
\text { minimum }\end{array}$ & 40 \\
\hline & A factor (Pa/\%torque) & 3.22 \\
\hline & M factor $\left(\mathrm{s}^{-1} / \% \mathrm{RPM}\right)$ & 11.7 \\
\hline & Shear rate range $\left(\mathrm{s}^{-1}\right)$ & $0-600$ \\
\hline & Ramp up time (min) & 5 \\
\hline & Hold time (min) & 1 \\
\hline & Ramp down time (min) & 5 \\
\hline
\end{tabular}

\subsection{Results and Discussion}

TIC and TOC results are presented in Table 3-1. The results have been corrected for dilution, and results for both replicates, along with the average, are provided.

Table 3-1. Total Inorganic and Organic Carbon Results

\begin{tabular}{|c|c|c|c|c|}
\hline \multirow{2}{*}{ Sample } & \multicolumn{2}{|c|}{ Inorganic Carbon } & \multicolumn{2}{c|}{ Organic Carbon } \\
\cline { 2 - 2 } & Result (mg/kg) & \multirow{2}{*}{ Average( mg/kg) } & $\begin{array}{c}\text { Result } \\
\text { (mg/kg) }\end{array}$ & $\begin{array}{c}\text { Average } \\
\text { (mg/kg) }\end{array}$ \\
\hline ORNL_24_A & 2,800 & \multirow{2}{*}{3,000} & 2,800 & \multirow{2}{*}{3,000} \\
\hline ORNL_24_B & 3,200 & & 3,200 & \multirow{2}{*}{1,850} \\
\hline ORNL_25_A & 2,300 & \multirow{2}{*}{2,000} & 2,000 & \multirow{2}{*}{$<1,500$} \\
\hline ORNL_25_B & 1,700 & & 1,700 & \multirow{2}{*}{1,600} \\
\hline ORNL_28_A & 2,000 & \multirow{2}{*}{2,050} & 1,500 & $<1,500$ \\
\hline ORNL_28_B & 2,100 & \multirow{2}{*}{2,750} & 1,700 & \multirow{2}{*}{} \\
\hline ORNL_30_A & 3,000 & 2,500 & & \\
\hline ORNL_30_B & 2,500 & \\
\hline
\end{tabular}

Yield stress from the vane measurements of the settled samples after 24 hours of settling are provided in Table 3-2. The vane curves are presented in Figure A-1 through Figure A-4 at the rotational speed of $0.6 \mathrm{rpm}$ as decribed in section 2.2. The vane measurements were obtained at ambient SRNL Shielded Cells temperature (approximately $20^{\circ} \mathrm{C}$ ). The volumes of the settled solids were not measured.

Table 3-2. Vane 24 Hour Settled Solids Yield Stress of As-Received ORNL Samples

\begin{tabular}{|c|c|}
\hline Sample & $\begin{array}{c}\text { Yield Stress } \\
(\mathrm{Pa})\end{array}$ \\
\hline ORNL-24 & 58 \\
\hline ORNL-25 & 8.3 \\
\hline ORNL-28 & 72 \\
\hline ORNL-30 & 130 \\
\hline
\end{tabular}


Rheological results (Bingham Plastic yield stress and plastic viscosity) from the flow curves are presented in Table 3-3. All measurements were performed at $25^{\circ} \mathrm{C}$. The corresponding flow curves are given in Appendix A, Figure A-5 through Figure A-24. As can be seen in many of these flow curves, there are spikes in the sheer stress, especially on the up curves, as well in some of the down curves, indicating large particle interactions between the bob and cup. 
Table 3-3. Bingham Plastic Yield Stress and Plastic Viscosity For ORNL Samples

\begin{tabular}{|c|c|c|c|c|c|}
\hline Sample & wt $\%$ TSS & Measurement & $\begin{array}{l}\text { Yield Stress } \\
\quad(\mathrm{Pa})\end{array}$ & $\begin{array}{c}\text { Plastic } \\
\text { Viscosity (cP) }\end{array}$ & $\mathrm{R}^{2}$ \\
\hline \multirow{7}{*}{ ORNL-24 } & \multirow{2}{*}{27.22} & 1 & 22.8 & 19.2 & 0.9841 \\
\hline & & 2 & \multicolumn{3}{|c|}{ Yield stress off-set not recorded } \\
\hline & \multirow{2}{*}{15} & 1 & \multicolumn{3}{|c|}{ Data is too noisy - solids impact } \\
\hline & & 2 & 1.0 & 5.1 & 0.9652 \\
\hline & \multirow{3}{*}{10} & 1 & 0.2 & 2.5 & 0.9674 \\
\hline & & 2 & 0.0 & 2.6 & 0.9574 \\
\hline & & Average & 0.1 & 2.6 & \\
\hline \multirow{9}{*}{ ORNL-25 } & \multirow{4}{*}{17.78} & 1 & 3.3 & 7.6 & 0.9875 \\
\hline & & 2 & 3.4 & 7.1 & 0.9860 \\
\hline & & 3 & 3.7 & 7.2 & 0.9829 \\
\hline & & Average & 3.5 & 7.3 & \\
\hline & \multirow[t]{2}{*}{15} & 1 & \multicolumn{3}{|c|}{ Solids impacting flow curve } \\
\hline & & 2 & 1.7 & 5.8 & 0.9725 \\
\hline & \multirow{3}{*}{10} & 1 & 0.1 & 4.0 & 0.9755 \\
\hline & & 2 & 0.1 & 3.0 & 0.9590 \\
\hline & & Average & 0.1 & 3.5 & \\
\hline \multirow{8}{*}{ ORNL-28 } & \multirow{2}{*}{16.23} & 1 & 19.1 & 20.0 & 0.9784 \\
\hline & & 2 & \multicolumn{3}{|c|}{ Yield stress off-set not recorded } \\
\hline & \multirow{3}{*}{10} & 1 & 3.4 & 7.6 & 0.9587 \\
\hline & & 2 & 2.9 & 6.9 & 0.9892 \\
\hline & & Average & 3.2 & 7.3 & \\
\hline & \multirow{3}{*}{5} & 1 & 0.0 & 2.6 & 0.9708 \\
\hline & & 2 & 0.0 & 2.5 & 0.9661 \\
\hline & & Average & $\mathbf{0 . 0}$ & 2.6 & \\
\hline \multirow{8}{*}{ ORNL-30 } & \multirow{2}{*}{29.65} & 1 & 33.0 & 26.0 & 0.9236 \\
\hline & & 2 & \multicolumn{3}{|c|}{ Yield stress off-set not recorded } \\
\hline & \multirow{3}{*}{15} & 1 & 0.3 & 4.0 & 0.9578 \\
\hline & & 2 & 0.2 & 3.7 & 0.9760 \\
\hline & & Average & 0.3 & 3.8 & \\
\hline & \multirow{3}{*}{$10 *$} & 1 & 0.0 & 2.5 & 0.9593 \\
\hline & & 2 & 0.0 & 2.7 & 0.9463 \\
\hline & & Average & 0.0 & 2.6 & \\
\hline
\end{tabular}

* Note that the yield stress was set to zero for these measurements and the slope of the line was reported as the viscosity. This is a zero off-set issue related to the instrument and fluids cannot have negative yield stresses.

The Bingham Plastic yield stress and plastic viscosity versus the wt $\%$ TSS for the bolded items in Table 3-3 are plotted in Figure 3-1and Figure 3-2 respectively so as to compare the samples. ORNL-24 and ORNL-30 seem to have similar property responses with respect to wt\% TSS. The 
ORNL-28 rheological properties approach those of ORNL-24/30 at a lower wt\% TSS. The ORNL-25 sample seems to be fairly insensitive to wt\% TSS as compared to the other ORNL samples.

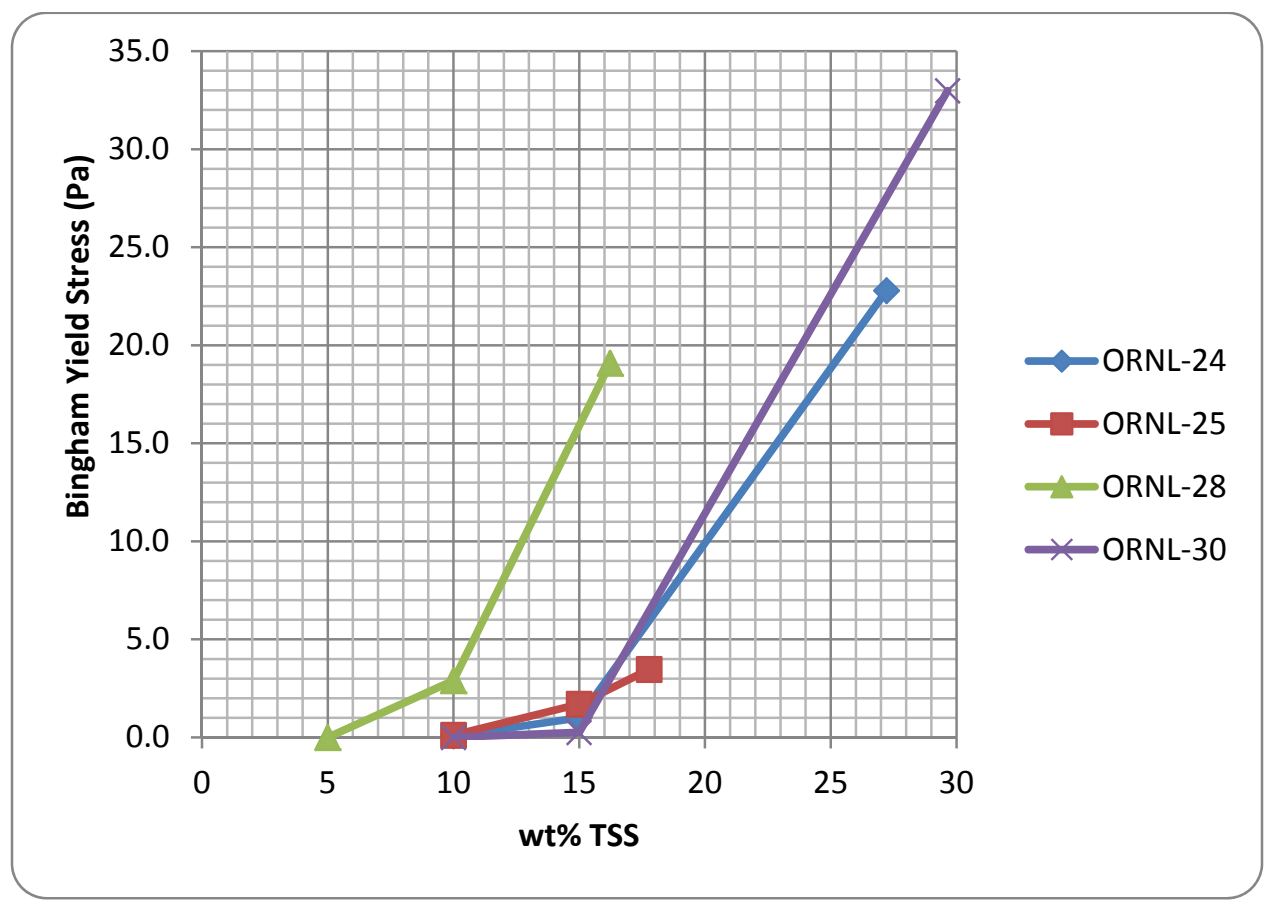

Figure 3-1 Bingham Plastic Yield Stress Versus Wt\% TSS for ORNL-24/25/28/30 Sludges

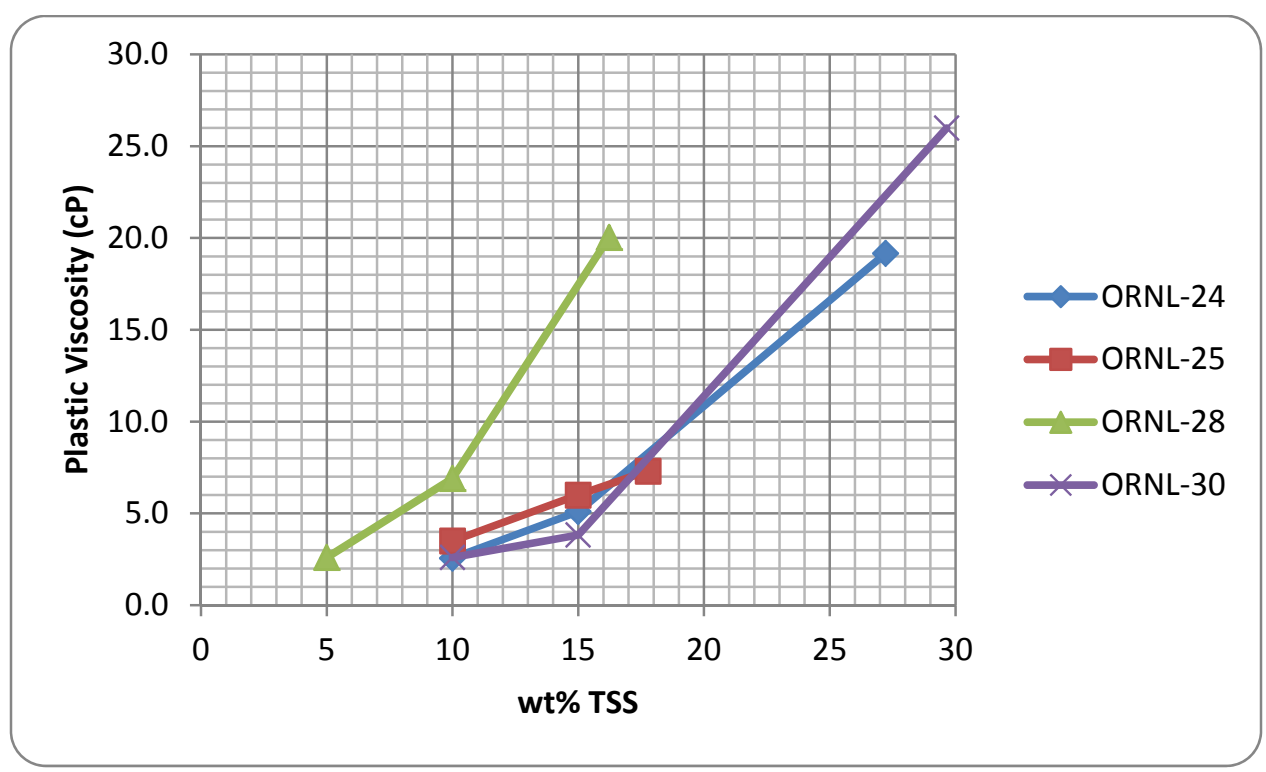

Figure 3-2 Plastic Viscosity Versus Wt\% TSS for ORNL-24/25/28/30 Sludges 


\subsection{Conclusion}

The TIC/TOC results are consistent between ORNL-25/28/30 samples. The ORNL-24 sample has a higher TIC/TOC as compared to the other ORNL samples.

The following rheological conclusions for the ORNL-24/25/28/30 sludge samples are:

1. Visually, all the ORNL samples seem to have cohesive properties.

2. All the ORNL samples seem to contain large particles that impact the flow curve measurements. Shear stress spikes, occurring in both the up and down flow curves is typical due to particles close to the gap distance (960 mircons) in at least one of the particle's dimension. The particles temporarily jam and release the rotor, causing these spikes. These large particles seem to have little impact on the overall rheological measurements. The shear stress spikes must be removed for curve fitting analysis of the data.

3. The Bingham Plastic yield stress and plastic viscosity versus wt $\%$ TSS for ORNL-24 and ORNL-30 are similar, indicating a common response to dilution.

4. The rheological flow properties of ORNL-25 are the least sensitive to changes in wt\% TSS.

5. The rheological flow properties of ORNL-28 are the most sensitive to changes in wt\% TSS. The Bingham Plastic yield stress reaches the same Bingham Plastic yields stress of the ORNL-24/30 samples at approximately $10 \mathrm{wt} \%$ TSS lower as compared to these samples.

6. The settled solids yield stress is consistent with the Bingham Plastic yield stress, where ORNL-24/28/30 samples have a much larger yield stresses as compared to the ORNL-25 sample. 


\subsection{References}

${ }^{1}$ Liddell, P.V. and Boger D.V., "Yield Stress Measurements with the vane”, Journal of NonNewtonian Fluid Mechanics, Vol. 63, pp 235-261, 1996

${ }^{2}$ Nguyen, Q.D. and Boger D.V., "Yield Stress Measurements for Concentrated Suspensions”, Journal of Rheology, Vol. 27, pp 321-349, 1983

${ }^{3}$ Nguyen, Q.D. and Boger D.V., “Direct Yield Stress Measurement with the Vane Method”, Journal of Rheology”, Vol. 29, pp 335-347, 1985

${ }^{4}$ Barnes, H.A. and Nguyen, Q.D., "Review Rotating Vane Rheometry - a Review”, Journal of Non-Newtonian Fluid Mechanics, Vol. 98, pp 1-14, 2001

${ }^{5}$ Yoshimura, A. S., and Prud'Homme, P.K., “A Comparison of Techniques for Measuring Yield Stresses”, Journal of Rheology, Vol. 31, pp 699-710, 1987

${ }^{6}$ Steffe, J. F., "Rheological Methods in Food Processing Engineering”, Freeman Press, $2^{\text {nd }}$ edition, 1996

${ }^{7}$ Barnes, H. A. and Carnali, J. O., "The vane-in-cup as a novel rheometer geometry for shear thinning and thixotropic materials”, Journal of Rheology, Vol. 34, pp 841-866, 1990

${ }^{8}$ Darby, R., Chemical Engineering Fluid Mechanics, 2nd edition. Marcel Dekker: 2001 
SRNL-STI-2013-00299

Revision 0

Appendix A. Vane and Flow Curves 


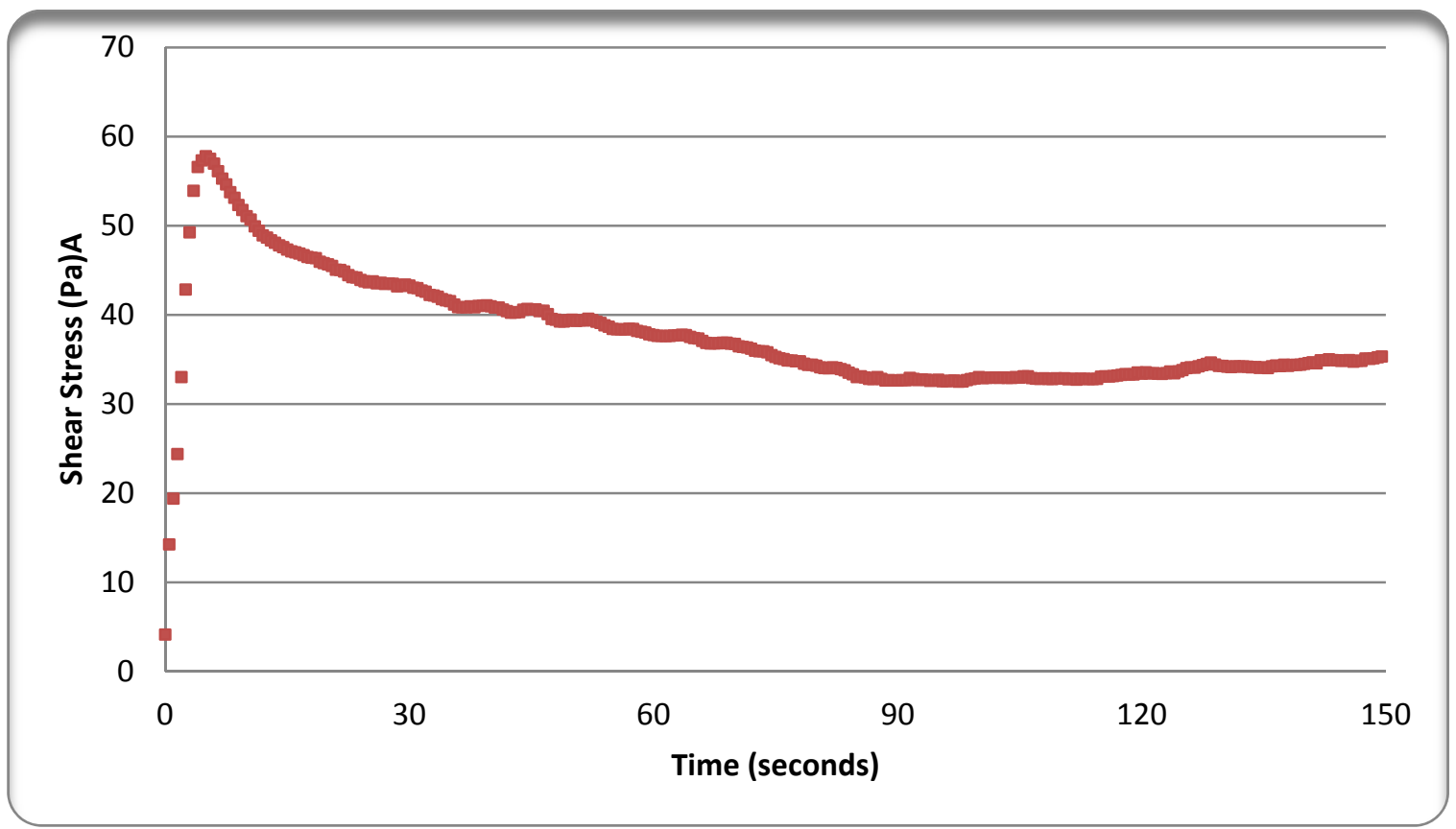

Figure A-1. ORNL-24 Vane Curve, 0.6 RPM

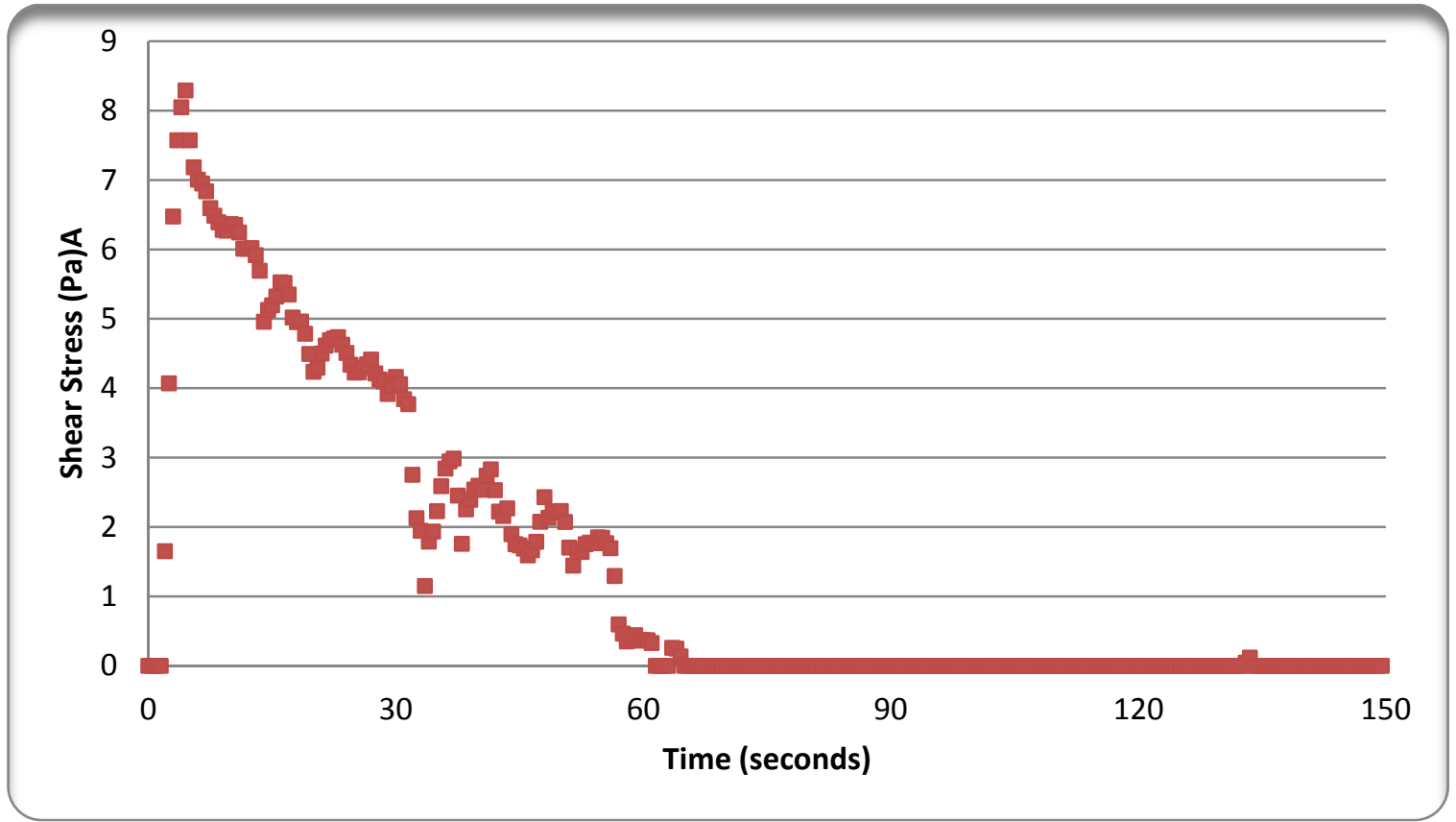

Figure A-2. ORNL-25 Vane Curve, 0.6 RPM 


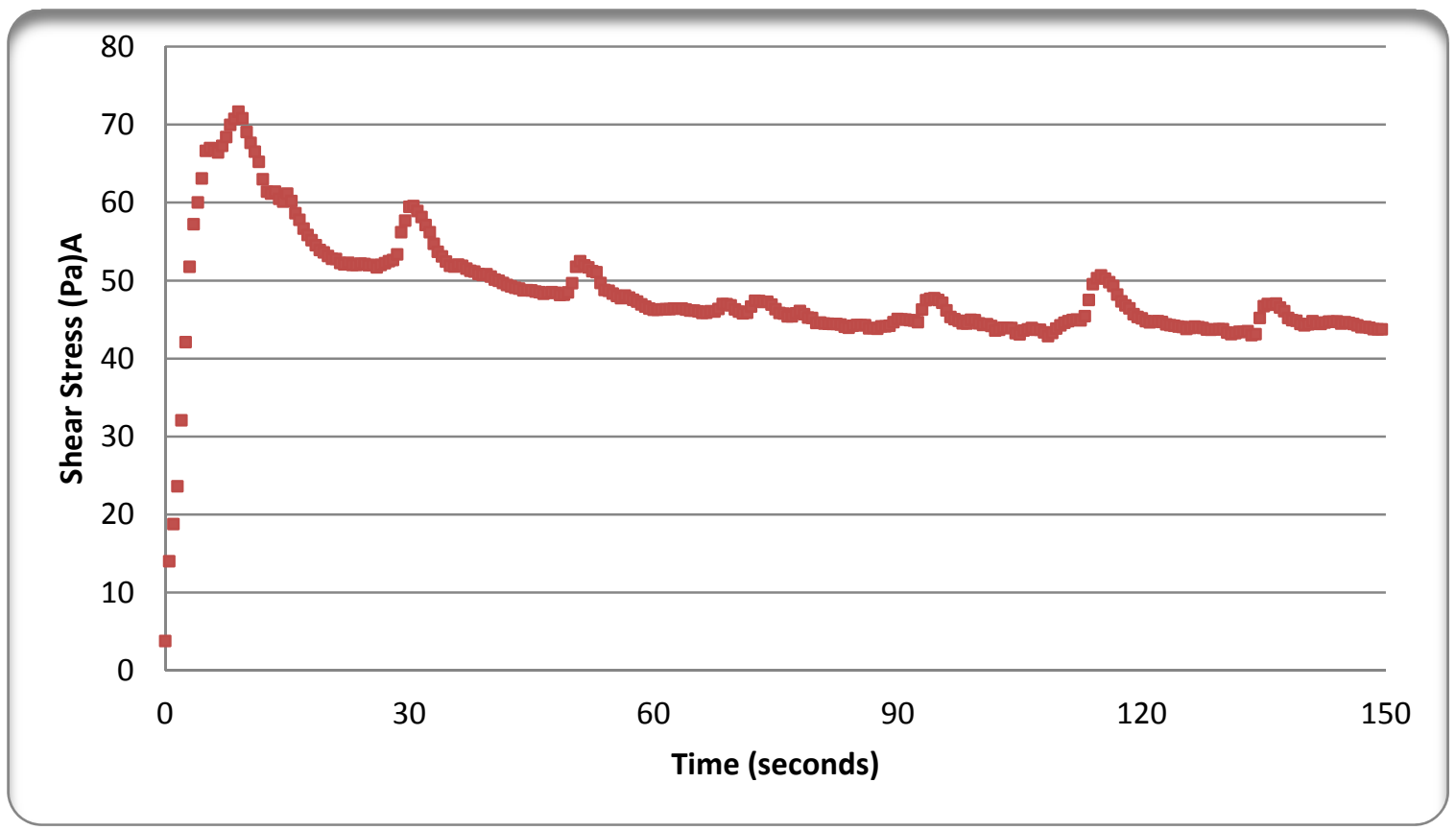

Figure A-3. ORNL-28 Vane Curve, 0.6 RPM

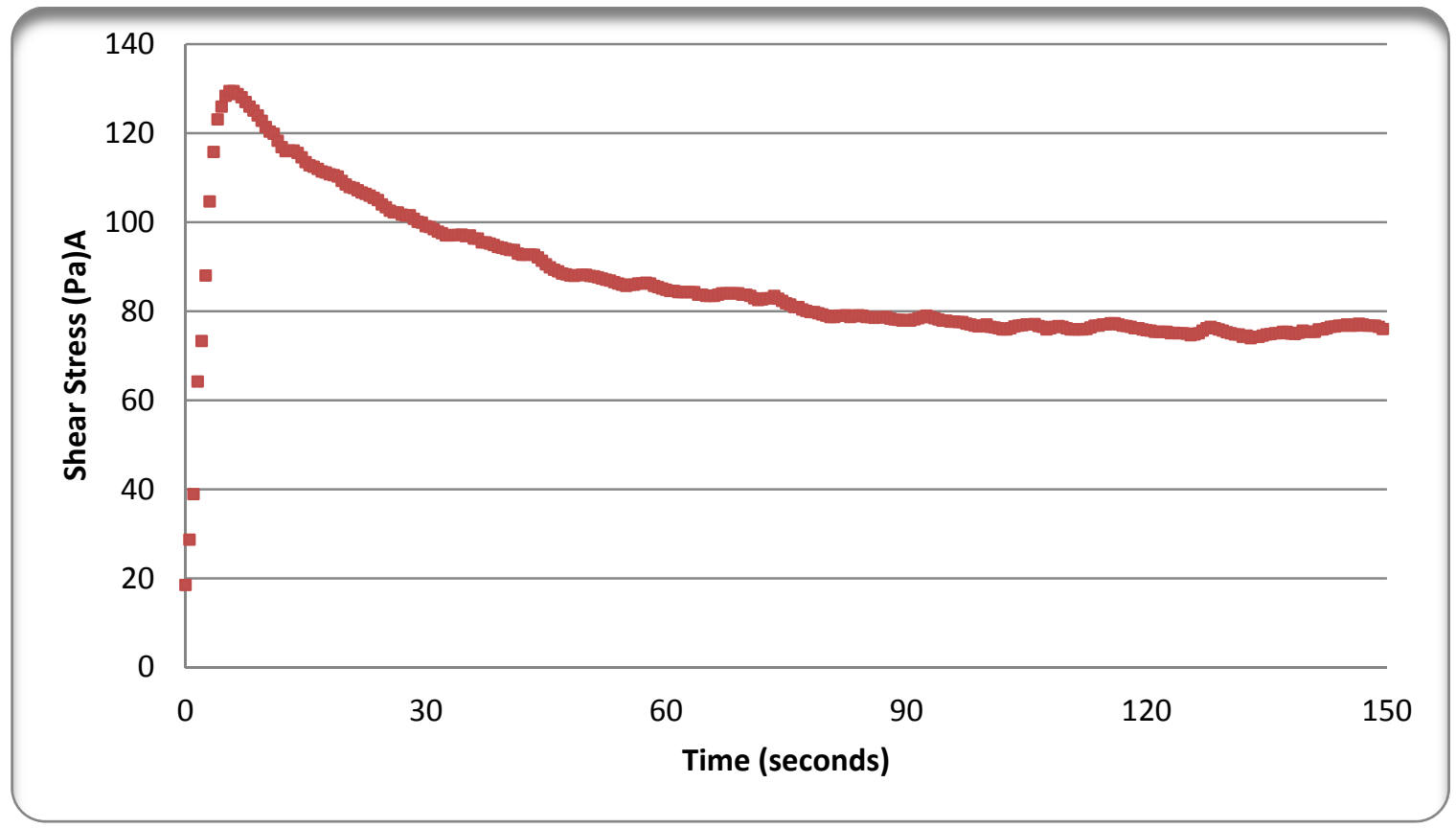

Figure A-4. ORNL-30 Vane Curve, 0.6 RPM 


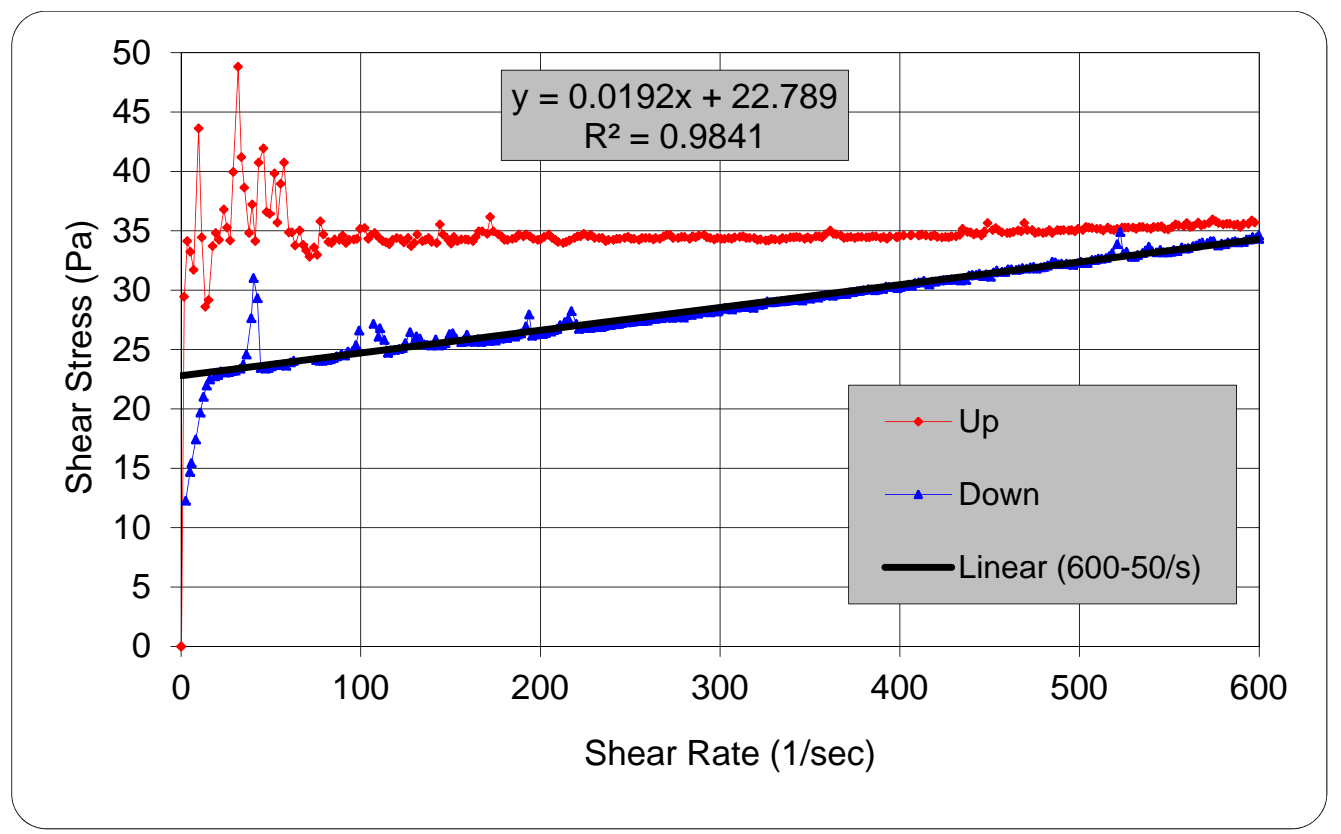

Figure A-5. ORNL-24 As-Received Flow Curve, $1^{\text {st }}$ Measurement

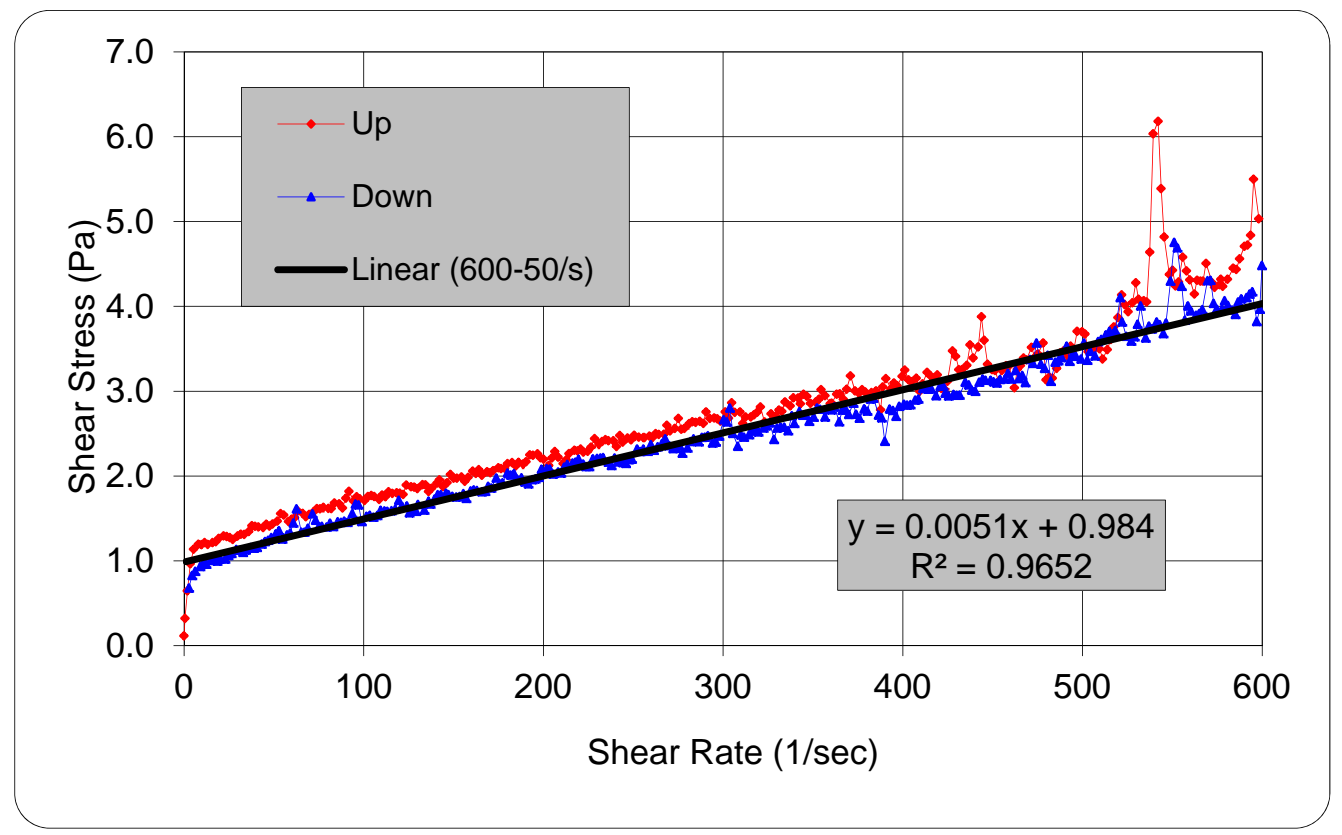

Figure A-6. ORNL-24 15\% TSS Flow Curve, $1^{\text {st }}$ Measurement 


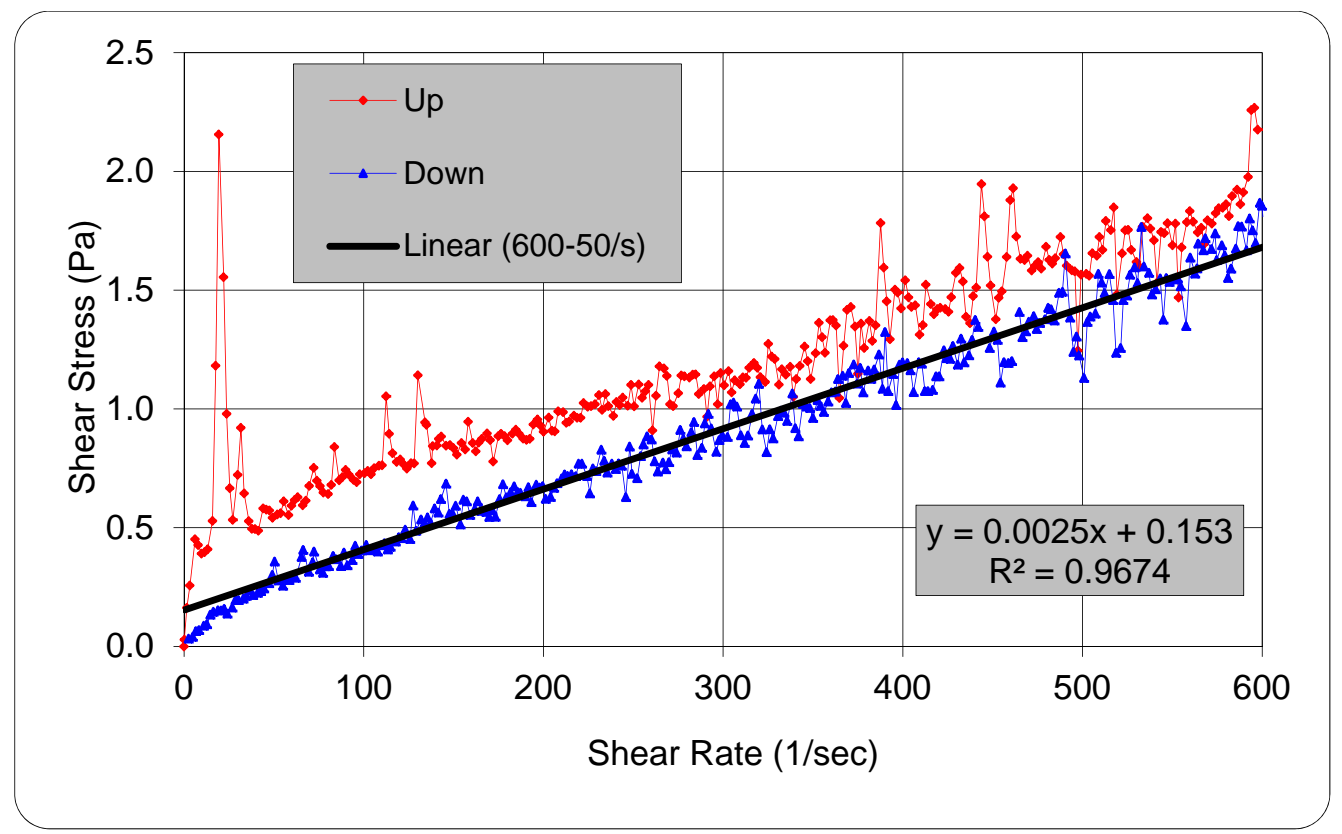

Figure A-7. ORNL-24 15\% TSS Flow Curve, $2^{\text {nd }}$ Measurement

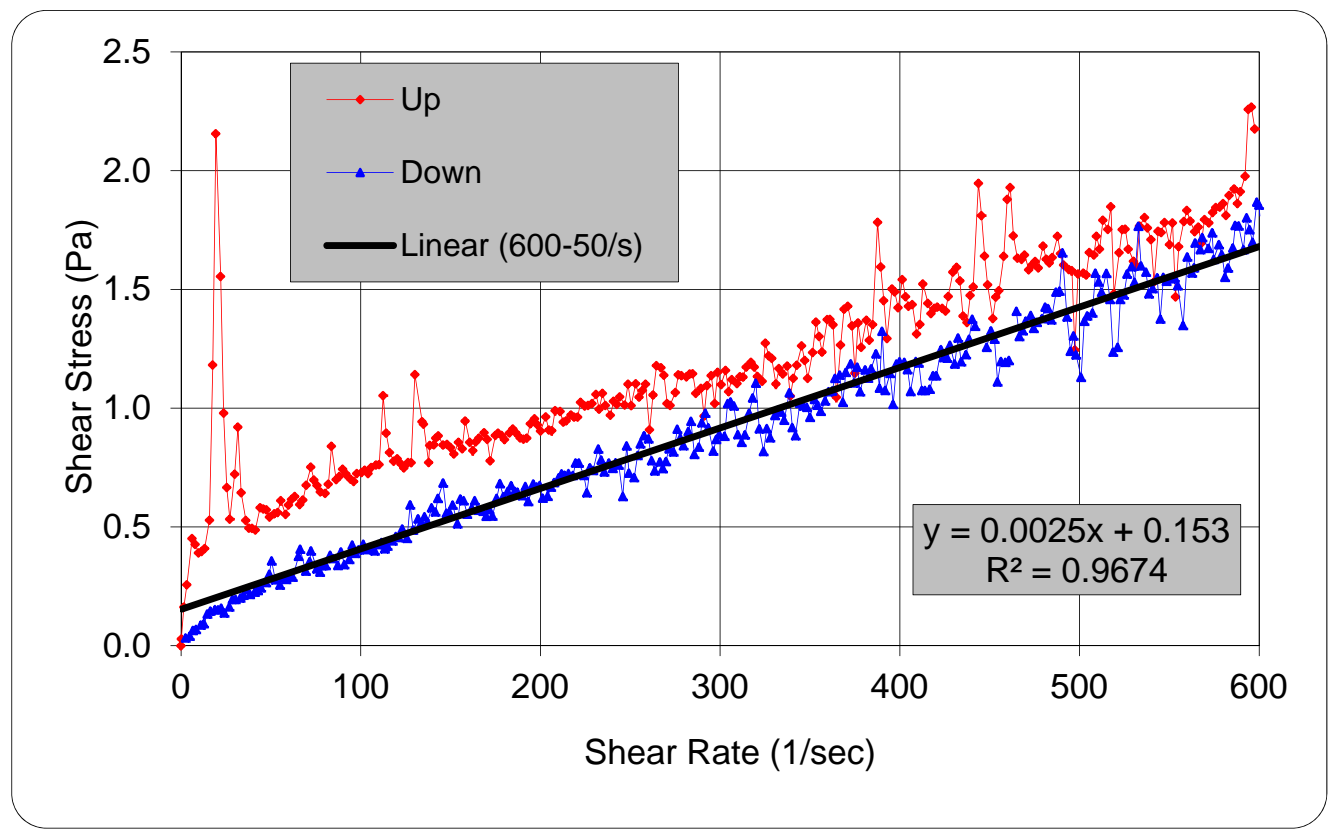

Figure A-8. ORNL-24 10\% TSS Flow Curve, $1^{\text {st }}$ Measurement 


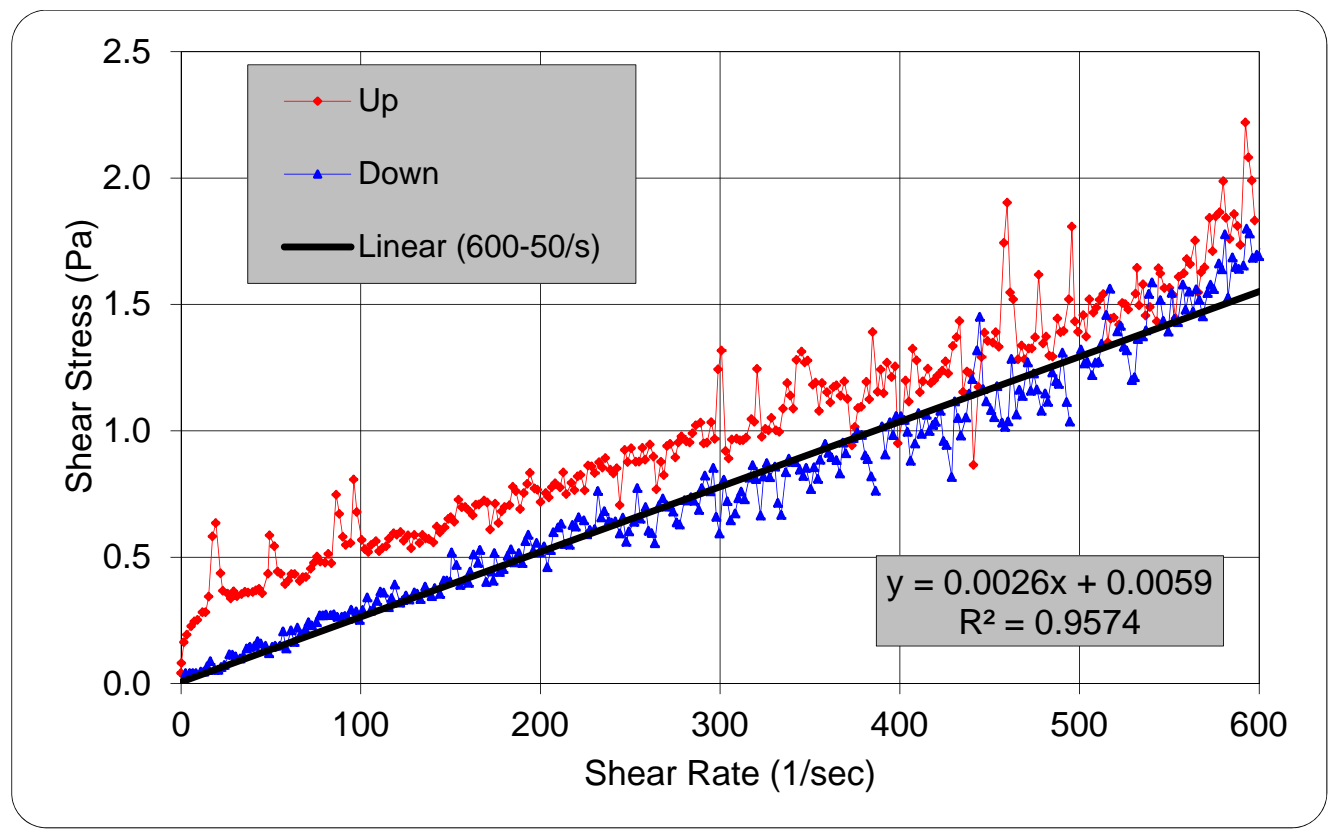

Figure A-9. ORNL-24 10\% TSS Flow Curve, $2^{\text {nd }}$ Measurement

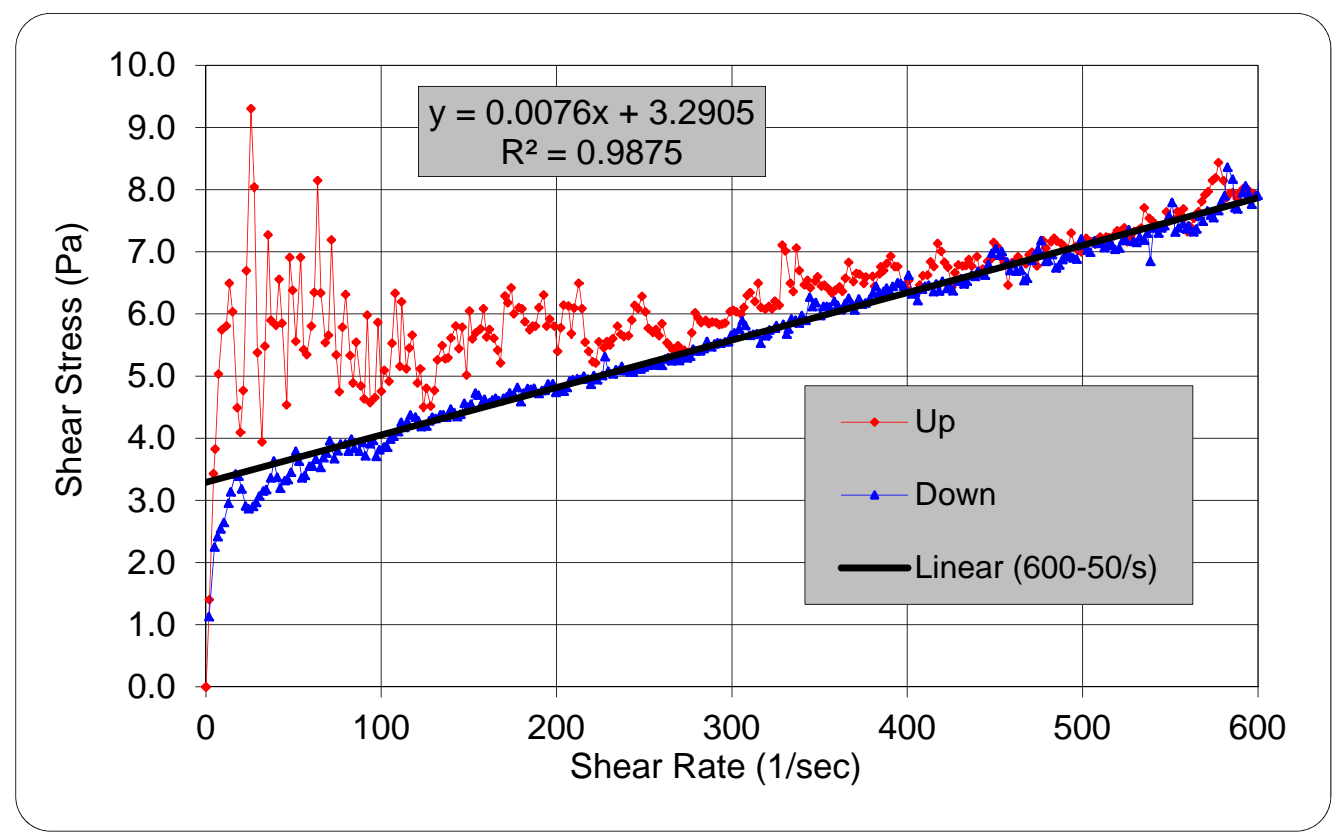

Figure A-10. ORNL-25 As-Received Flow Curve, $1^{\text {st }}$ Measurement 


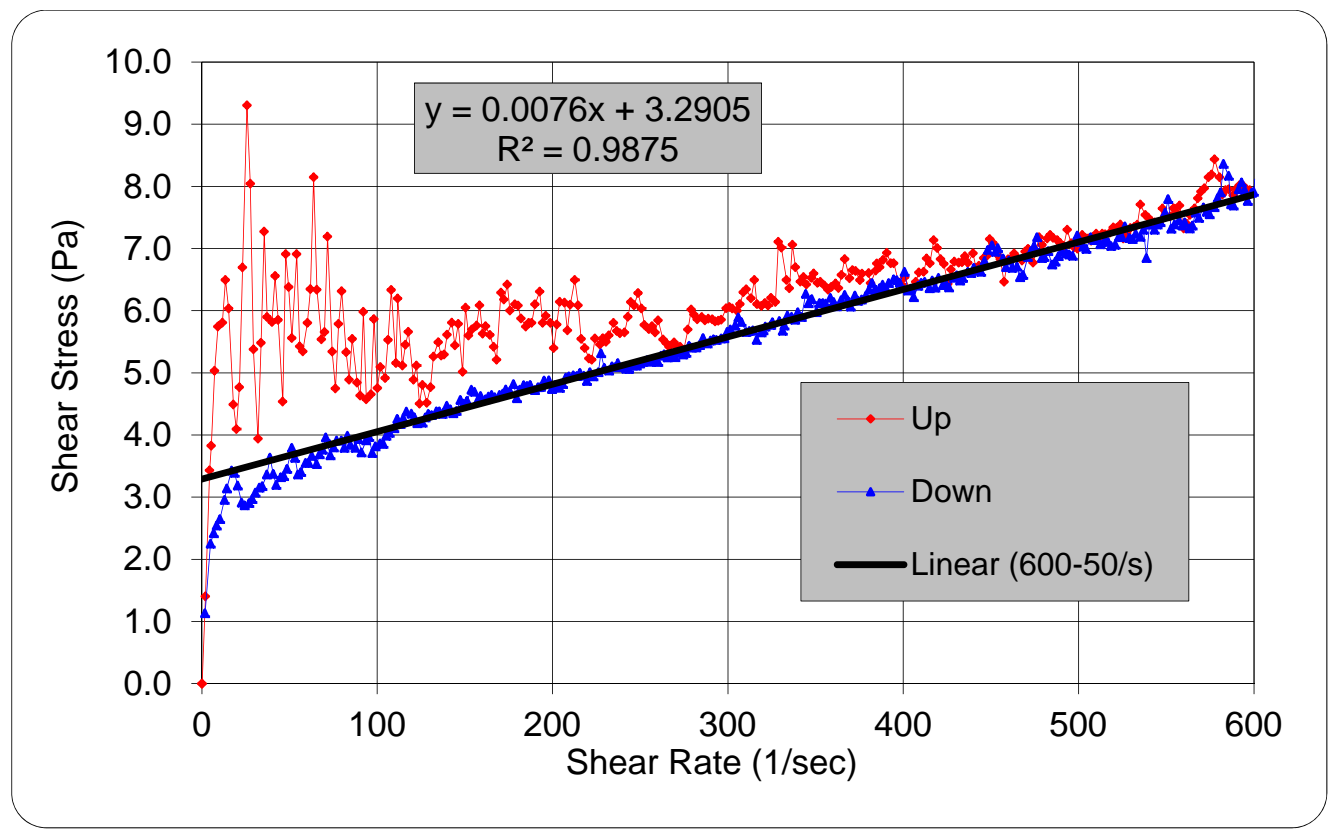

Figure A-11. ORNL-25 As-Received Flow Curve, $2^{\text {nd }}$ Measurement

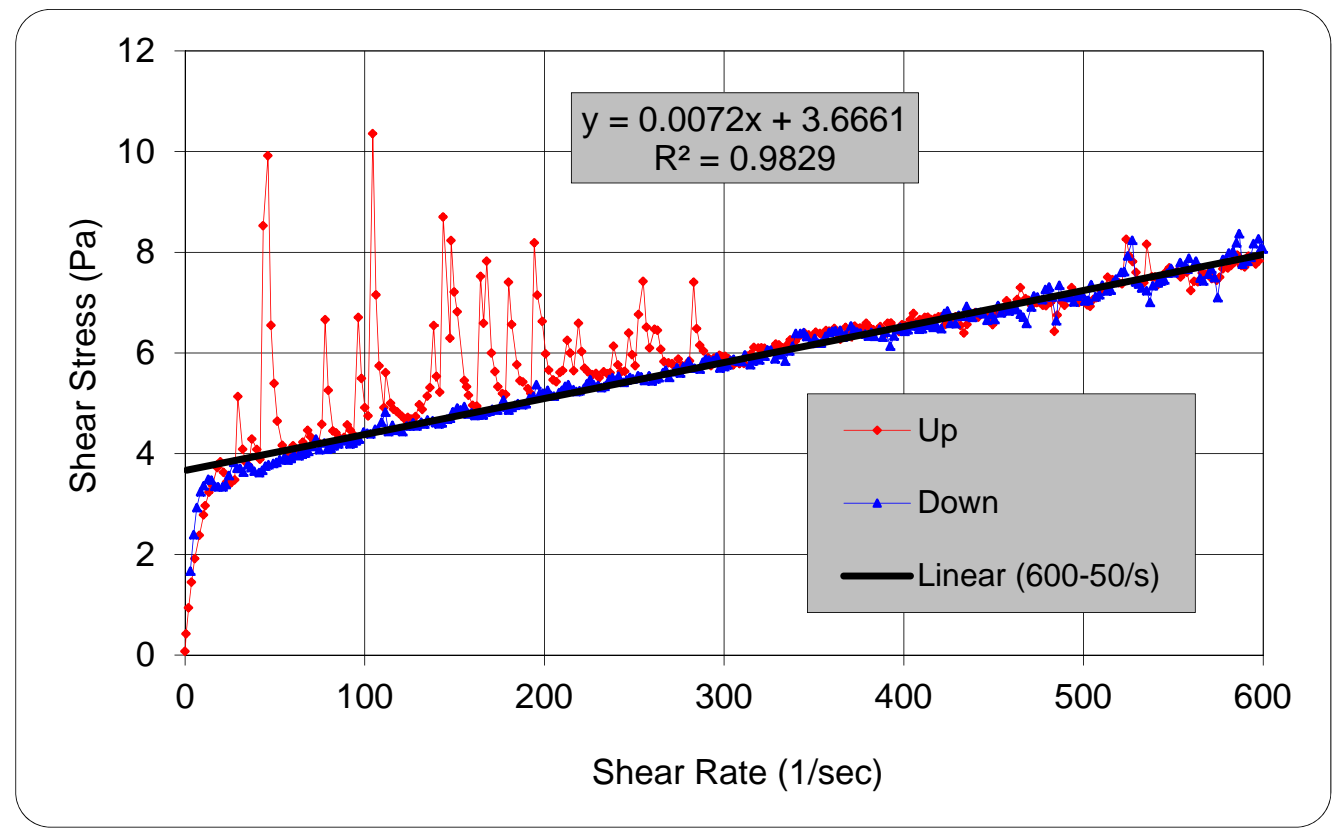

Figure A-12. ORNL-25 As-Received Flow Curve, $3^{\text {rd }}$ Measurement 


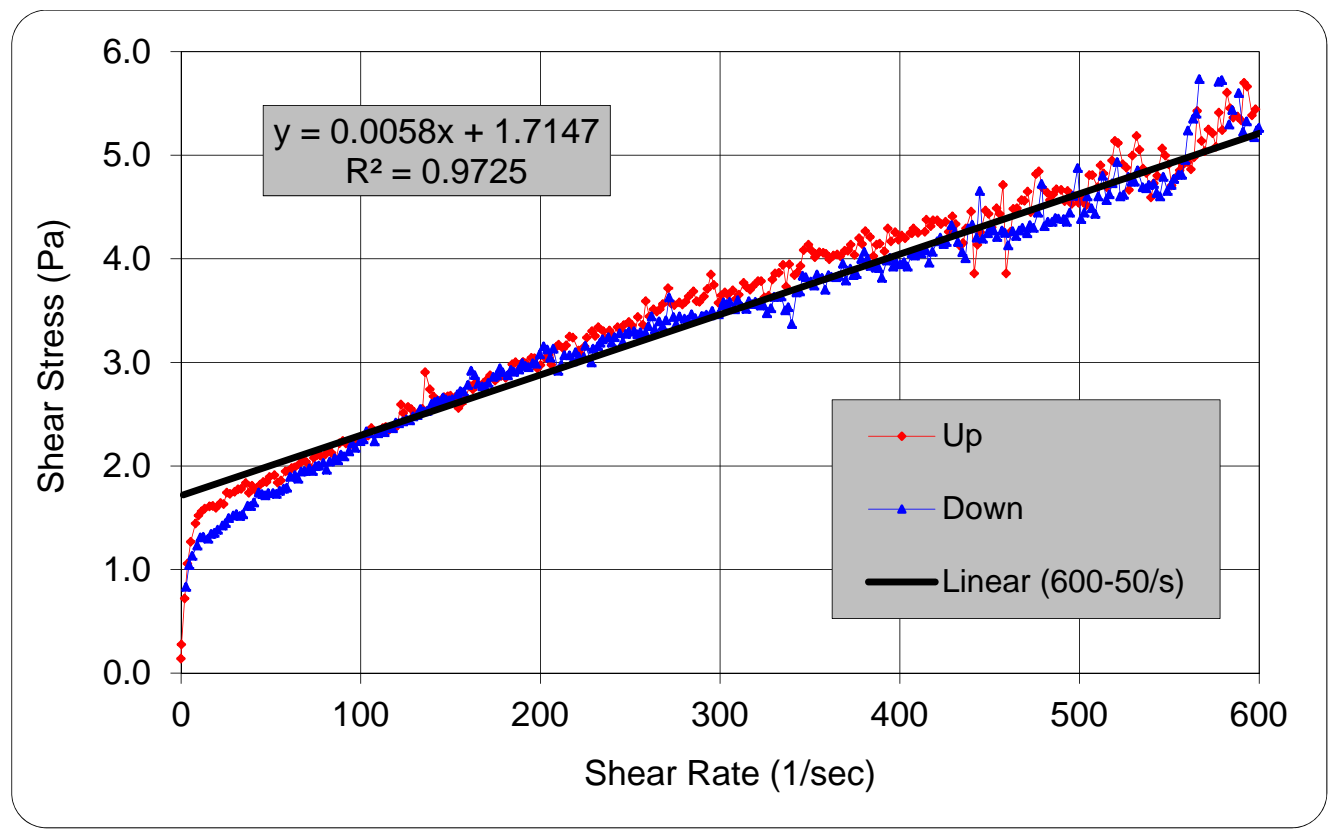

Figure A-13. ORNL-25 15\% TSS Flow Curve, $2^{\text {nd }}$ Measurement

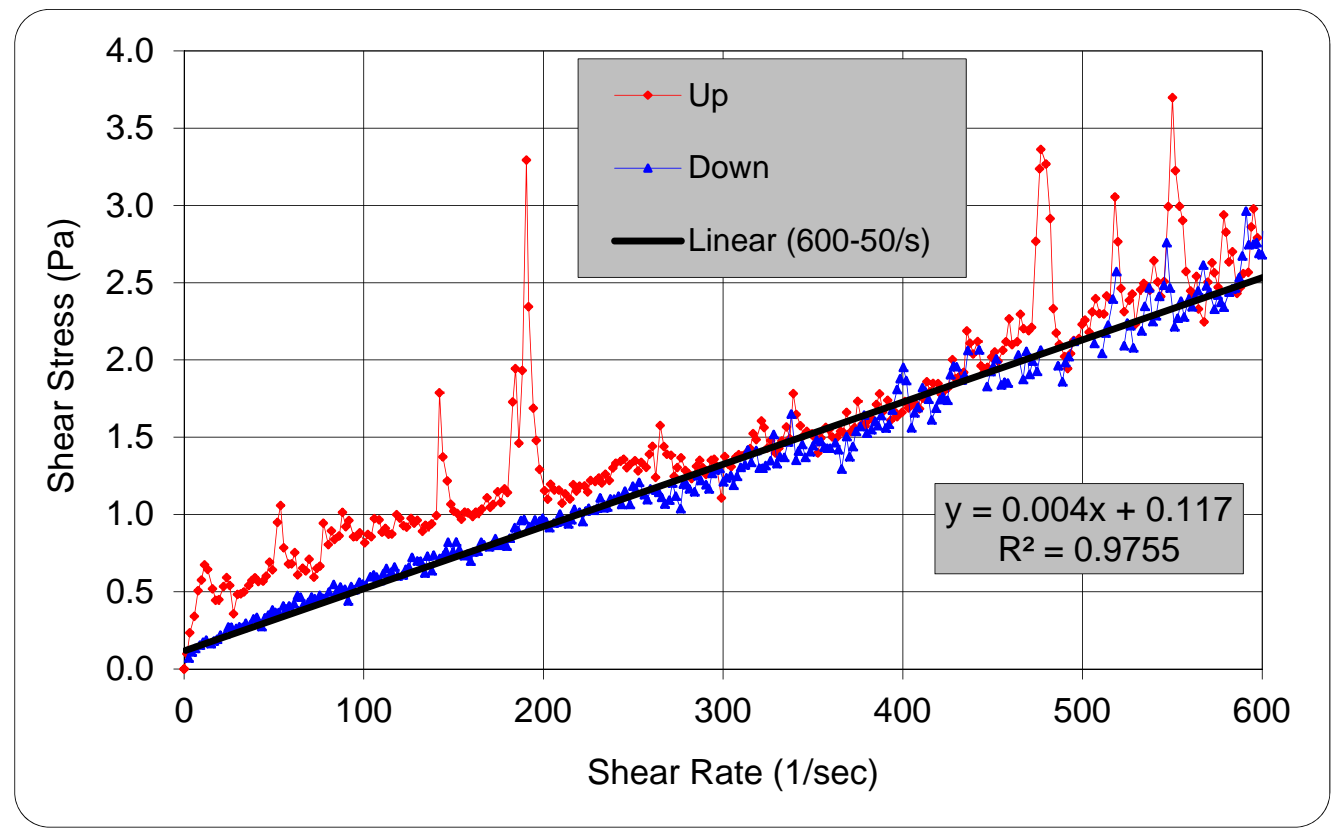

Figure A-14. ORNL-25 10\% TSS Flow Curve, $1^{\text {st }}$ Measurement 


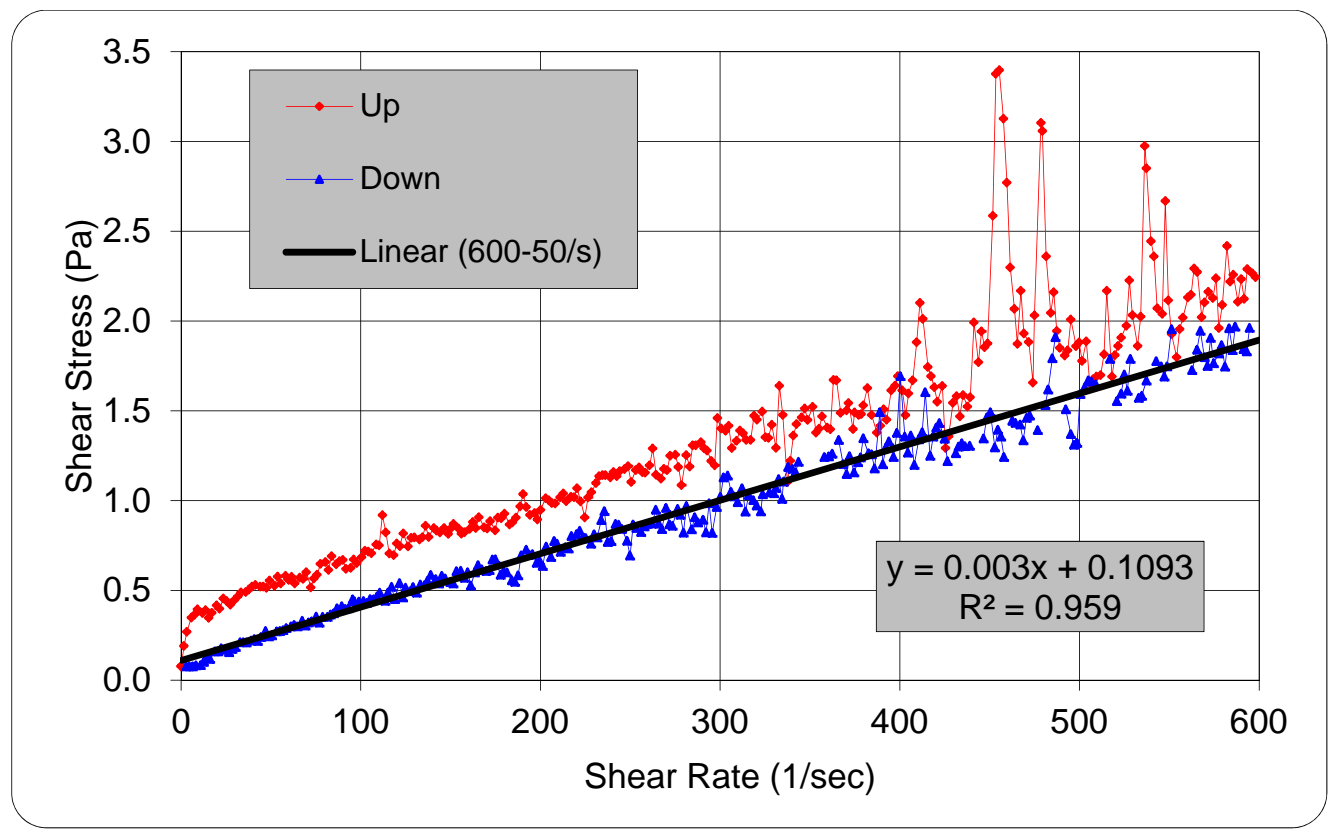

Figure A-15. ORNL-25 10\% TSS Flow Curve, $2^{\text {nd }}$ Measurement

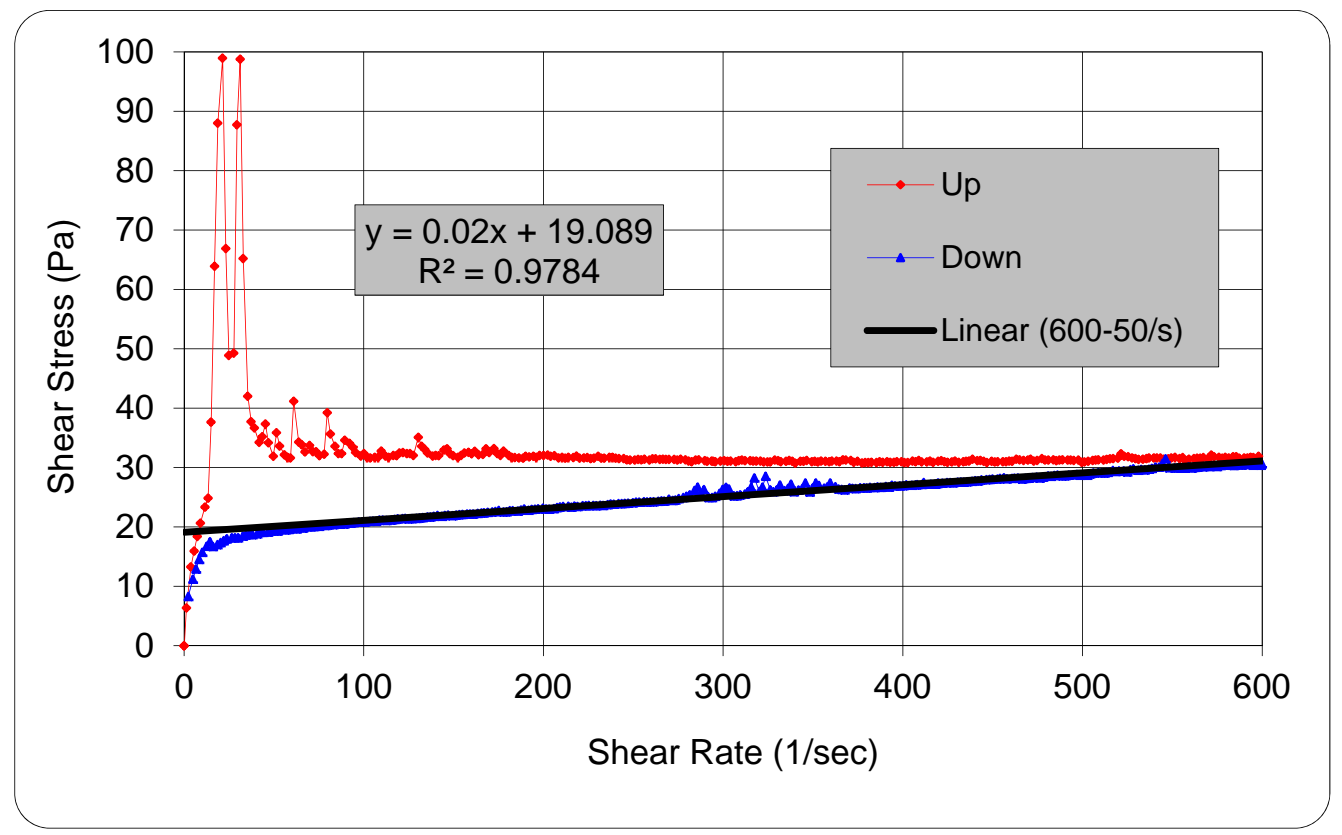

Figure A-16. ORNL-28 As-Received Flow Curve, $1^{\text {st }}$ Measurement 


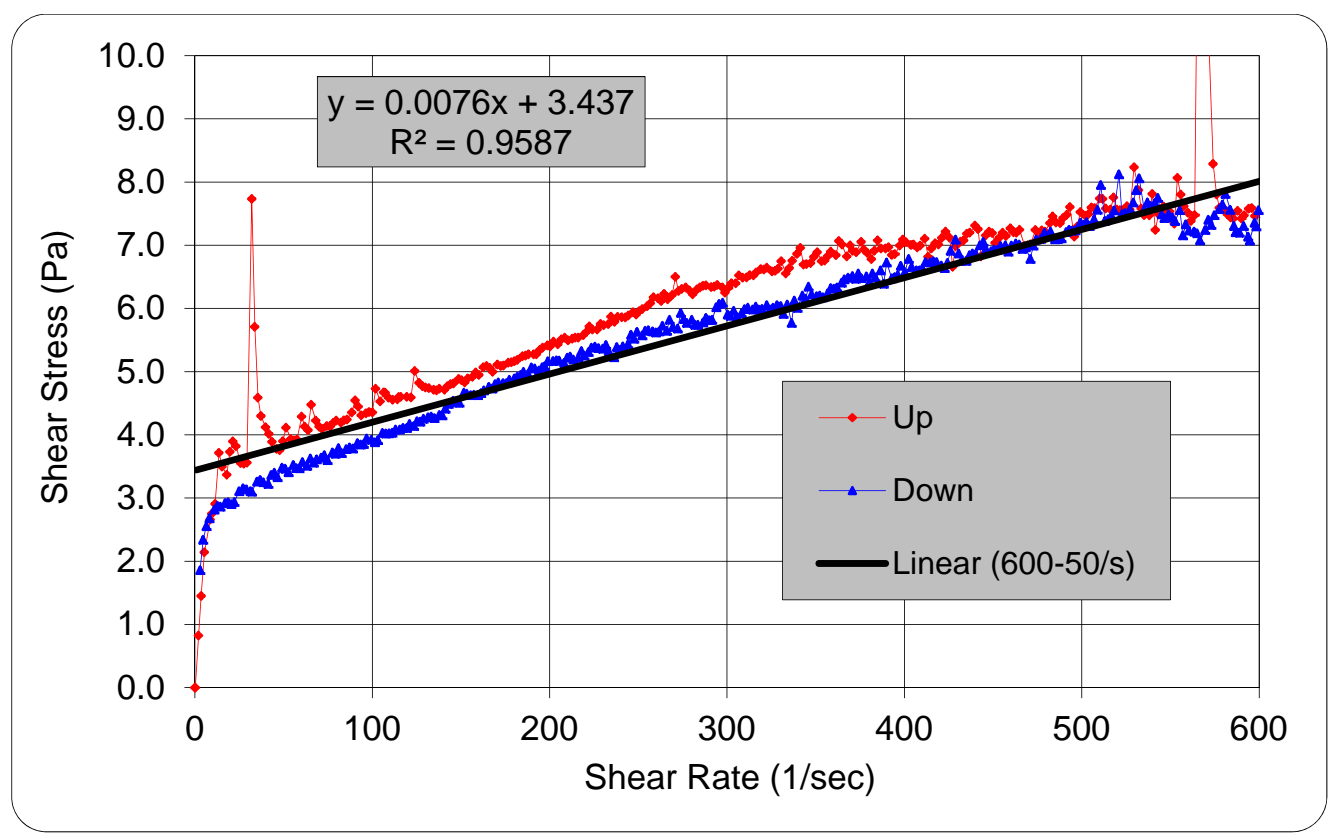

Figure A-17. ORNL-28 10\% TSS Flow Curve, $1^{\text {st }}$ Measurement

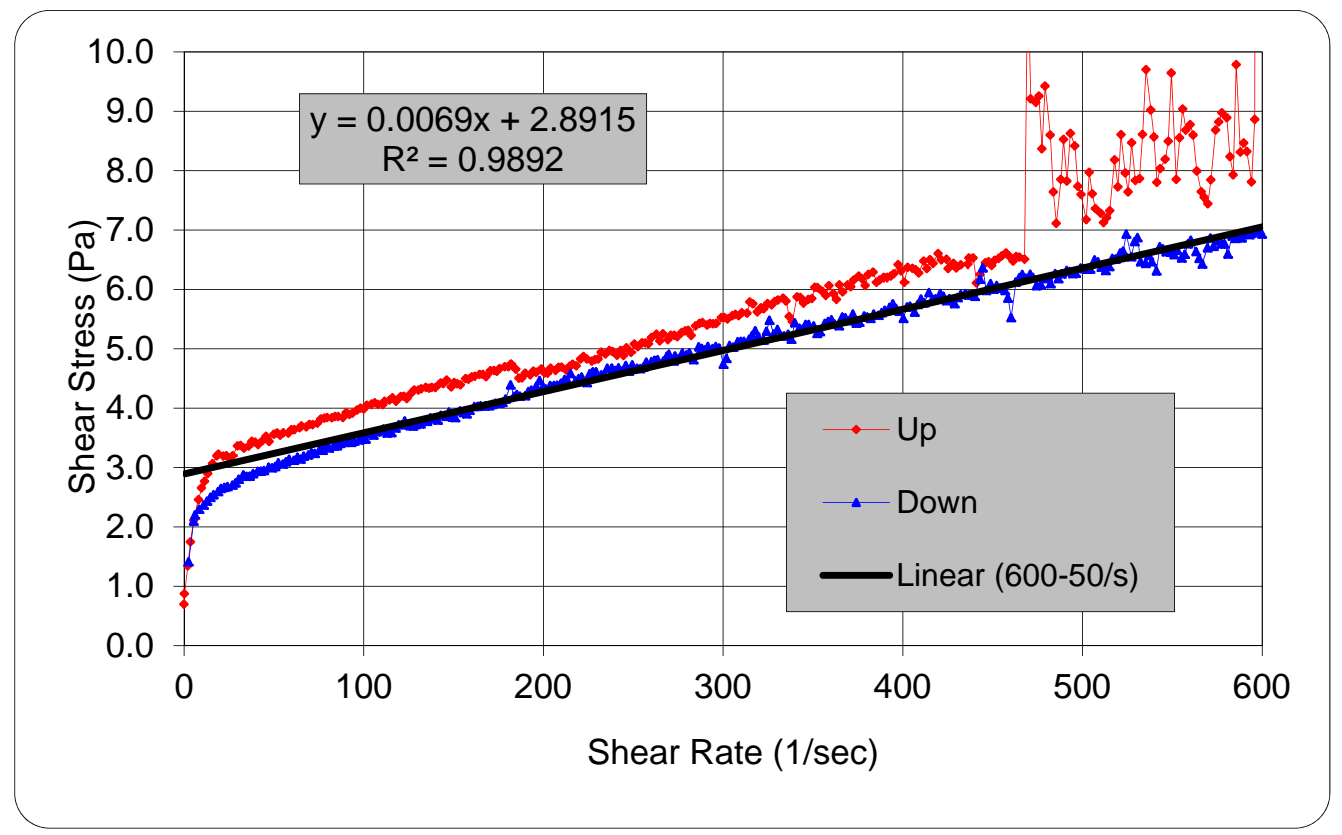

Figure A-18. ORNL-28 10\% TSS Flow Curve, $2^{\text {nd }}$ Measurement 


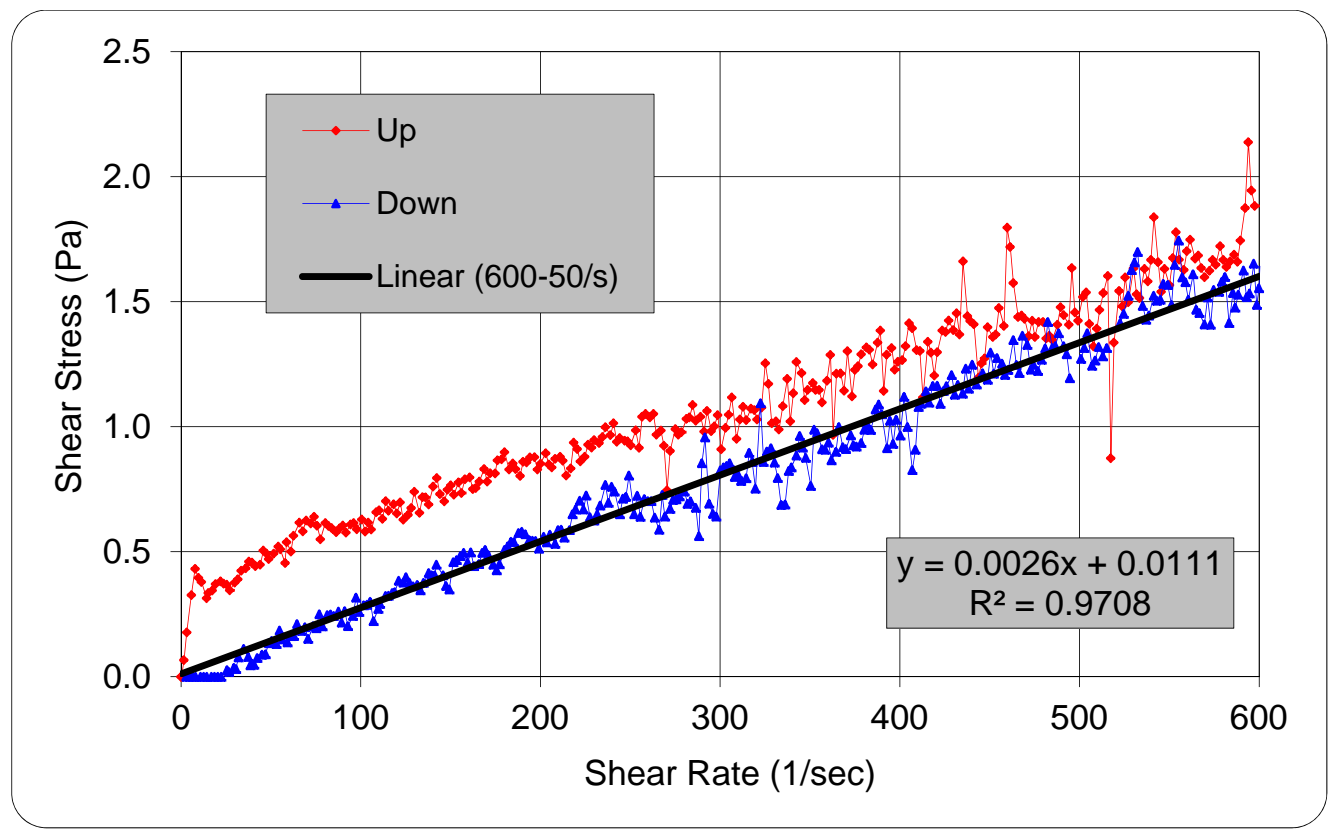

Figure A-19. ORNL-28 5\% TSS Flow Curve, $1^{\text {st }}$ Measurement

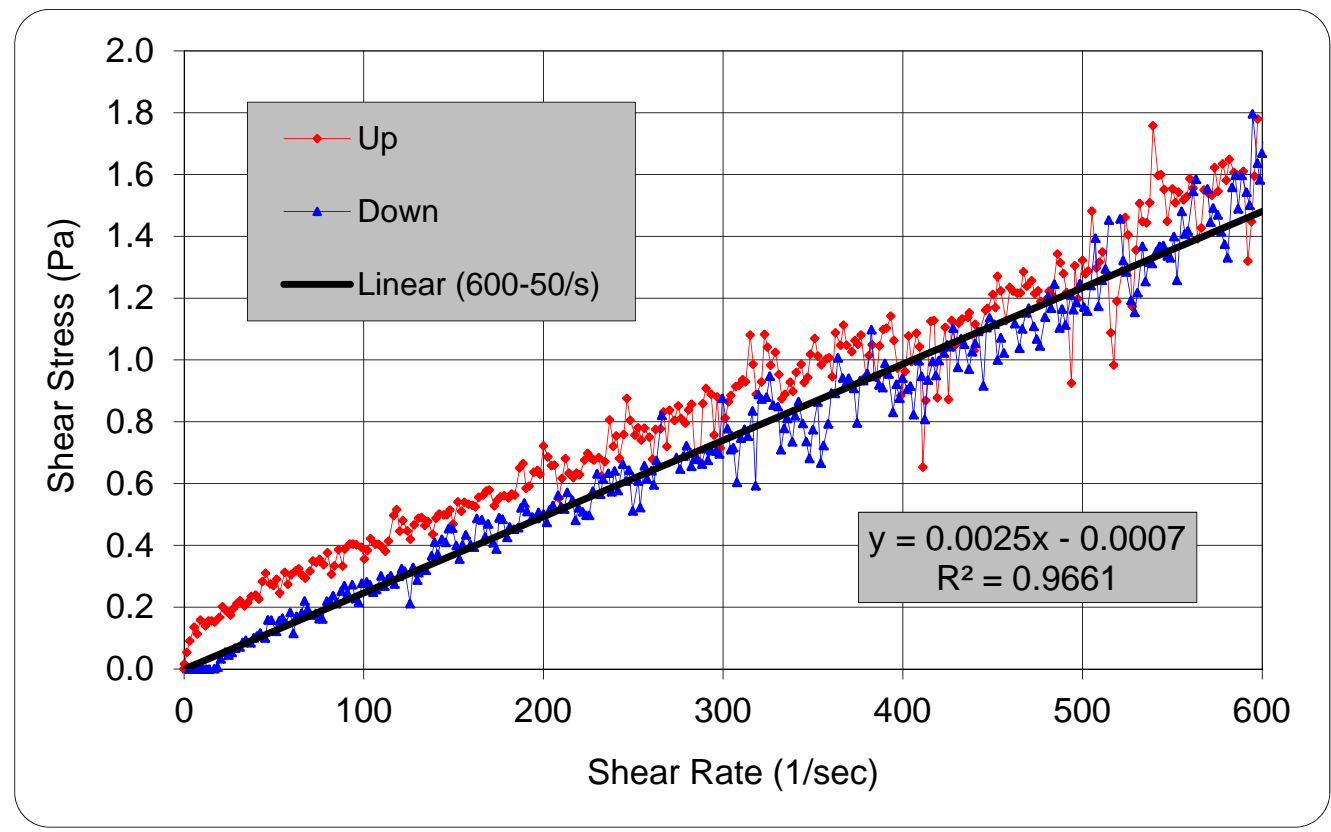

Figure A-20. ORNL-28 5\%TSS Flow Curve, $2^{\text {nd }}$ Measurement 


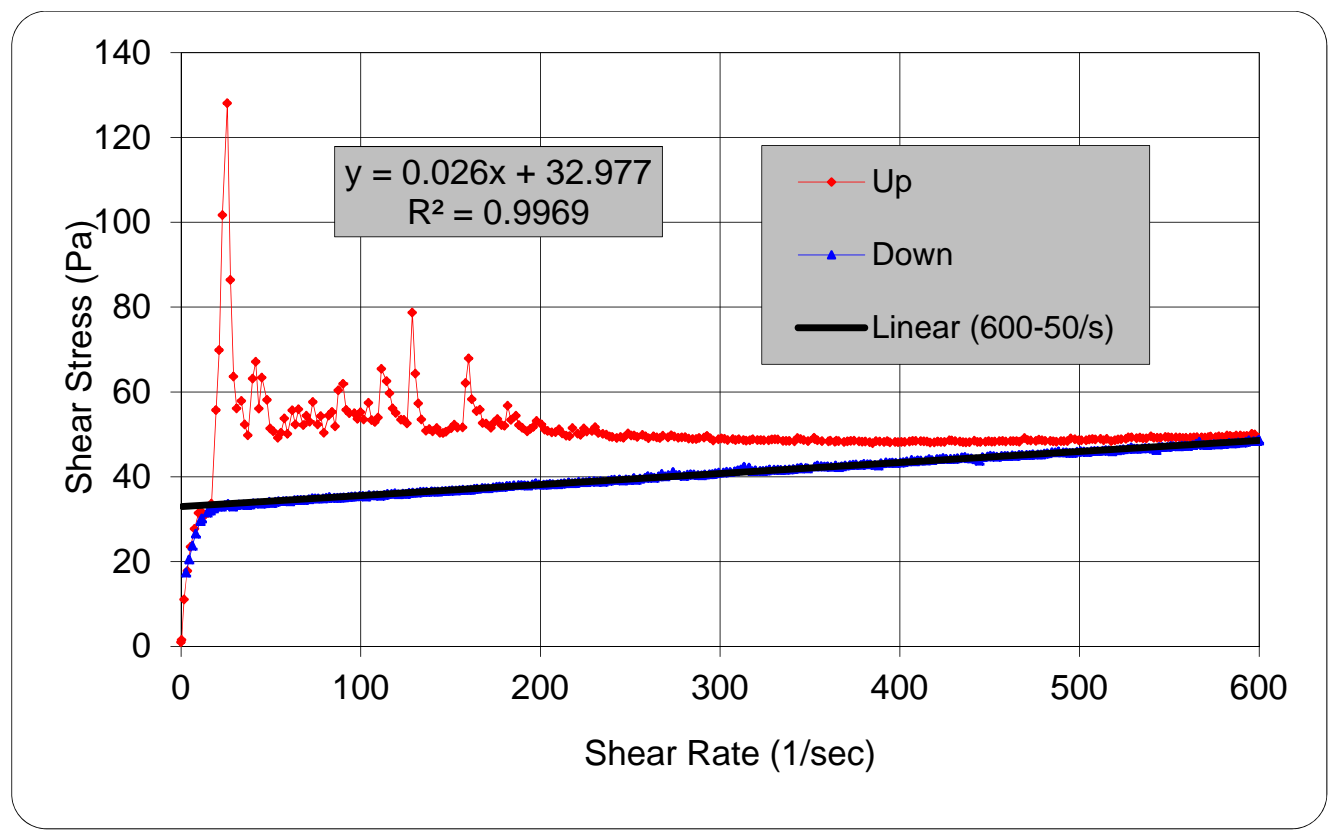

Figure A-21. ORNL-30 As-Received Flow Curve, $1^{\text {st }}$ Measurement

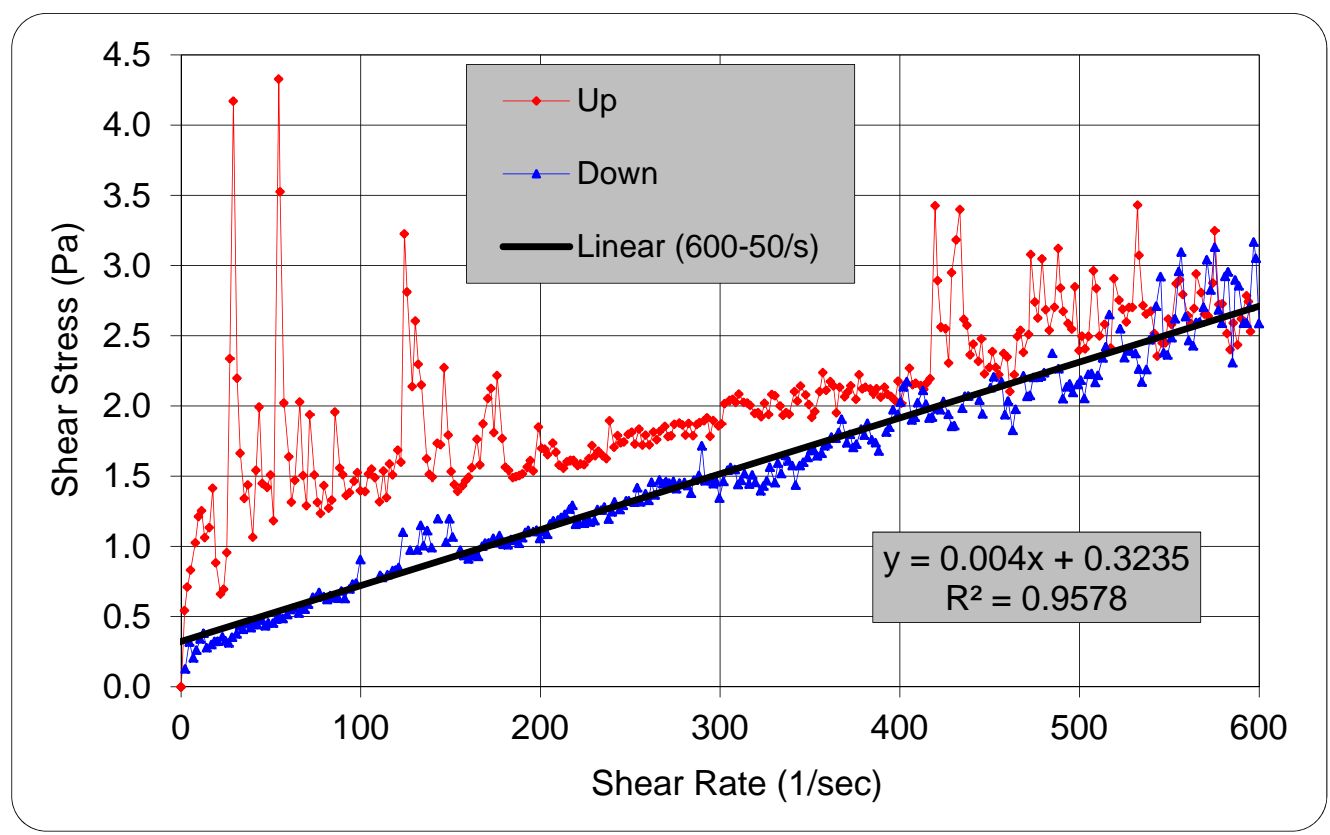

Figure A-22. ORNL-30 15\% TSS Flow Curve, $1^{\text {st }}$ Measurement 


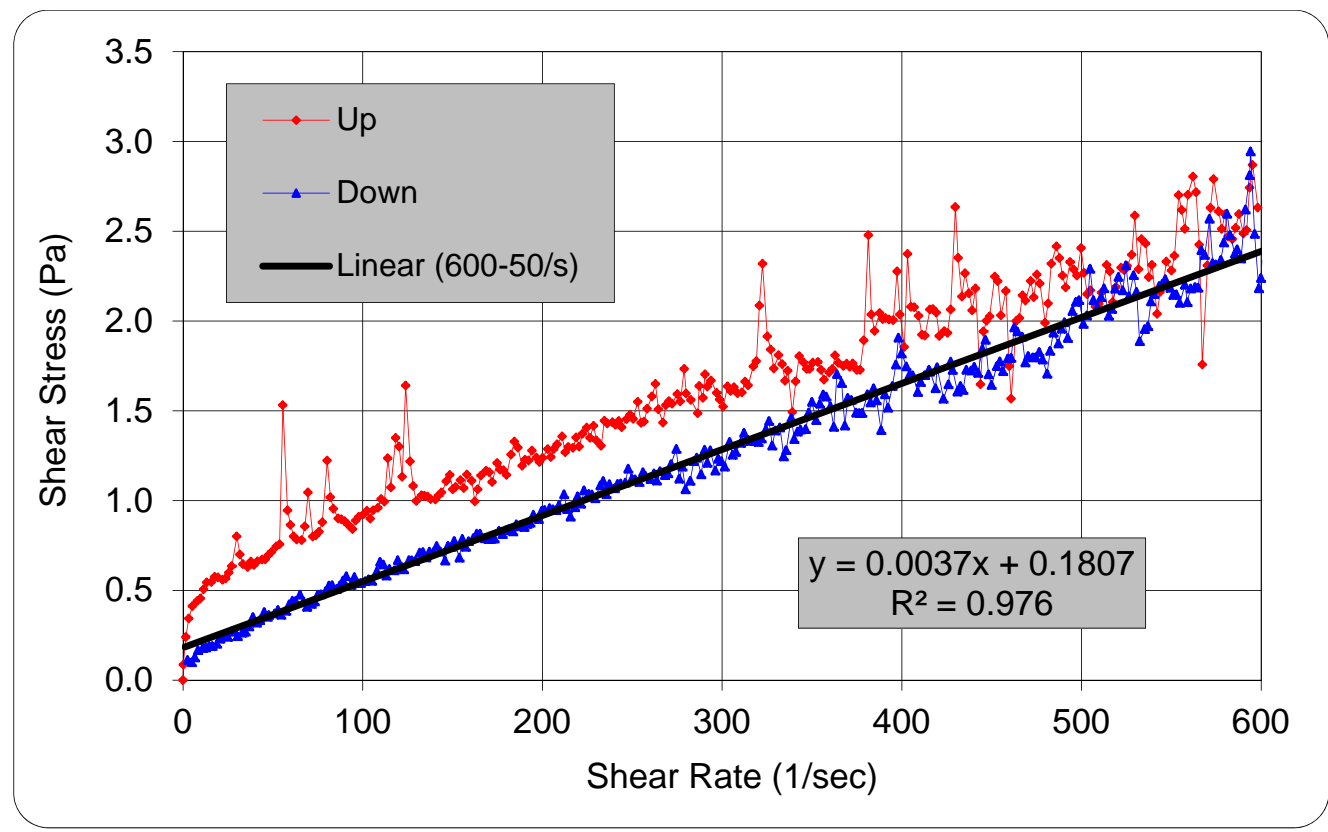

Figure A-23. ORNL-30 15\% TSS Flow Curve, $2^{\text {nd }}$ Measurement

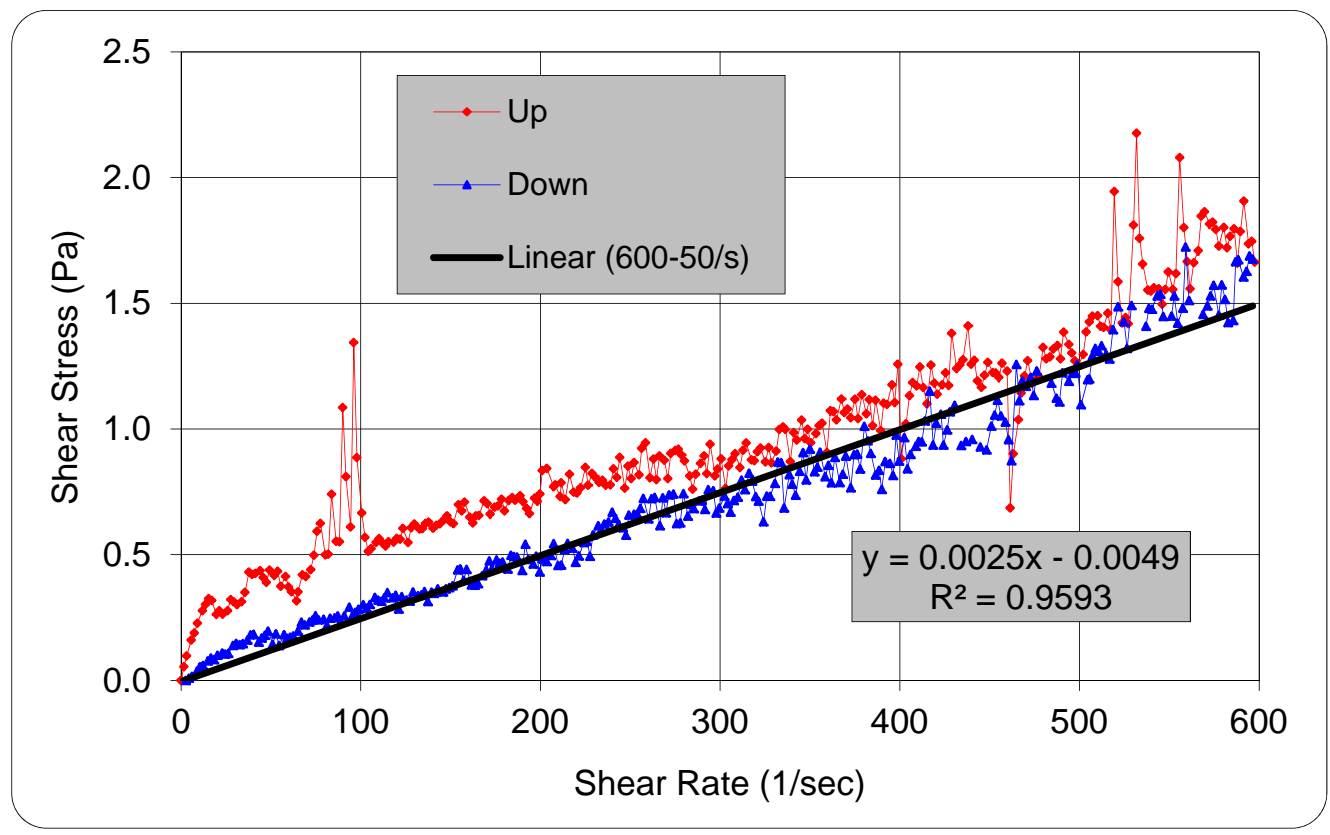

Figure A-24. ORNL-30 10\% TSS Flow Curve, $1^{\text {st }}$ Measurement 


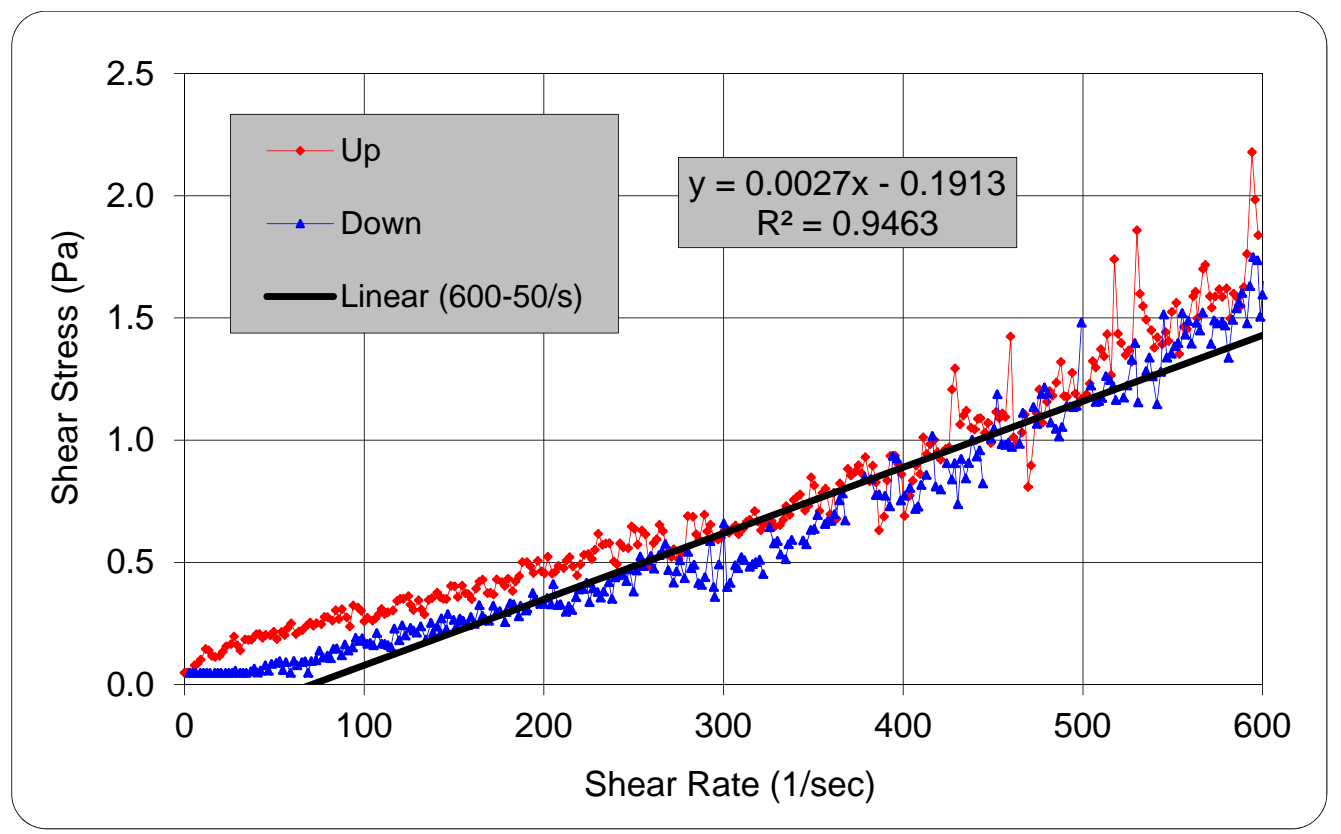

Figure A-25. ORNL-30 10\% TSS Flow Curve, $2^{\text {nd }}$ Measurement 